\title{
Controls on surface water carbonate chemistry along North American ocean margins
}

\author{
Wei-Jun Cai (1) ${ }^{1 凶}$, Yuan-Yuan Xu (1) ${ }^{1}$, Richard A. Feely ${ }^{2}$, Rik Wanninkhof ${ }^{3}$, Bror Jönsson (1) ${ }^{4}$, Simone R. Alin (D) ${ }^{2}$, \\ Leticia Barbero ${ }^{3,5}$, Jessica N. Cross ${ }^{2}$, Kumiko Azetsu-Scott ${ }^{6}$, Andrea J. Fassbender (1) ${ }^{7}$, Brendan R. Carter ${ }^{2,8}$, \\ Li-Qing Jiang ${ }^{9}$, Pierre Pepin ${ }^{10}$, Baoshan Chen (1) ${ }^{1}$, Najid Hussain ${ }^{1}$, Janet J. Reimer ${ }^{1}$, Liang Xue (i) ${ }^{11}$, \\ Joseph E. Salisbury ${ }^{12}$, José Martín Hernández-Ayón ${ }^{13}$, Chris Langdon (1) ${ }^{14}$, Qian Li (i) ${ }^{1}$, Adrienne J. Sutton (1) ${ }^{2}$, \\ Chen-Tung A. Chen (iD ${ }^{15}$ \& Dwight K. Gledhill ${ }^{16}$
}

Syntheses of carbonate chemistry spatial patterns are important for predicting ocean acidification impacts, but are lacking in coastal oceans. Here, we show that along the North American Atlantic and Gulf coasts the meridional distributions of dissolved inorganic carbon (DIC) and carbonate mineral saturation state $(\Omega)$ are controlled by partial equilibrium with the atmosphere resulting in relatively low DIC and high $\Omega$ in warm southern waters and the opposite in cold northern waters. However, $\mathrm{pH}$ and the partial pressure of $\mathrm{CO}_{2}\left(\mathrm{pCO}_{2}\right)$ do not exhibit a simple spatial pattern and are controlled by local physical and net biological processes which impede equilibrium with the atmosphere. Along the Pacific coast, upwelling brings subsurface waters with low $\Omega$ and $\mathrm{pH}$ to the surface where net biological production works to raise their values. Different temperature sensitivities of carbonate properties and different timescales of influencing processes lead to contrasting property distributions within and among margins.

\footnotetext{
${ }^{1}$ School of Marine Science and Policy, College of Earth, Ocean, and Environment, University of Delaware, 111 Robinson Hall, Newark, DE 19716, USA. ${ }^{2}$ NOAA Pacific Marine Environmental Laboratory, 7600 Sand Point Way NE, Seattle, WA 98115, USA. ${ }^{3}$ NOAA Atlantic Oceanographic and Meteorological Laboratory, 4301 Rickenbacker Causeway, Miami, FL 33149, USA. ${ }^{4}$ Plymouth Marine Laboratory, Prospect Place, Plymouth PL1 3DH, UK. ${ }^{5}$ Cooperative Institute for Marine \& Atmospheric Studies, University of Miami, 4600 Rickenbacker Causeway, Miami, FL 33149, USA. ${ }^{6}$ Fisheries and Oceans Canada, Bedford Institute of Oceanography, 1 Challenger Drive, Dartmouth, NS B2Y 4A2, Canada. ${ }^{7}$ Monterey Bay Aquarium Research Institute, 7700 Sandholdt Road, Moss Landing, CA 95039, USA. ${ }^{8}$ Joint Institute for the Study of the Atmosphere and Ocean, University of Washington, 3737 Brooklyn Avenue NE, Seattle, WA 98195, USA. ${ }^{9}$ Earth System Science Interdisciplinary Center, University of Maryland, College Park, MD 20740, USA. ${ }^{10}$ Department of Fisheries and Oceans, Northwest Atlantic Fisheries Centre, St. John's, NL, Canada. ${ }^{11}$ First Institute of Oceanography, Ministry of Natural Resources, 266061 Qingdao, China. ${ }^{12}$ Ocean Process Analysis Laboratory, University of New Hampshire, Durham, NH 03824, USA. ${ }^{13}$ Instituto de Investigaciones Oceanológicas, Universidad Autónoma de Baja California, Ensenada, Baja California, Mexico. ${ }^{14}$ Department of Marine Biology and Ecology, University of Miami, 4600 Rickenbacker Causeway, Miami, FL 33149, USA. ${ }^{15}$ Department of Oceanography, National Sun Yat-sen University, Kaohsiung 80424, Taiwan, ROC. ${ }^{16}$ NOAA Ocean Acidification Program, 1315 East-West Highway, Silver Spring, MD 20910, USA. $\varpi_{\text {email: wcai@udel.edu }}$
} 
A bsorption of anthropogenic $\mathrm{CO}_{2}$ from the atmosphere has acidified the ocean, as indicated by increases in sea surface $p \mathrm{CO}_{2}$ and hydrogen ion concentration $\left(\left[\mathrm{H}^{+}\right]\right)$and decreases in $\mathrm{pH}$, carbonate ion concentration $\left(\left[\mathrm{CO}_{3}^{2-}\right]\right)$, and calcium carbonate $\left(\mathrm{CaCO}_{3}\right)$ mineral saturation state $\mathrm{e}^{1-5}$. The latter is a ratio of the ionic product, $\left[\mathrm{Ca}^{2+}\right]\left[\mathrm{CO}_{3}^{2-}\right]$, to its saturated value below which $\mathrm{CaCO}_{3}$ dissolution may occur (in this paper we only target the saturation state of aragonite, $\Omega_{\mathrm{arag}}$, a mineral form that comprises the shells and hard parts of corals, mollusks, and many other marine organisms). More than a decade of ocean acidification research has improved our understanding of the mechanisms controlling the global spatial patterns and temporal variations of ocean carbonate chemistry ${ }^{5-8}$, and has begun to reveal how ocean chemistry (e.g., $\mathrm{pH}$ and $\left.\Omega_{\text {arag }}\right)^{9-13}$ and marine organisms ${ }^{14-16}$ are responding to anthropogenic $\mathrm{CO}_{2}$ uptake. In coastal regions, much of the ocean acidification research has focused on examining how anthropogenic $\mathrm{CO}_{2}$-induced acidification is mitigated or exacerbated by biological production (removing $\mathrm{CO}_{2}$ ) in surface waters and subsequent respiration (adding $\mathrm{CO}_{2}$ ) in subsurface waters as a result of natural nutrient enrichment or human-induced coastal eutrophication ${ }^{17-20}$. Attention has also been given to the effects of biological community composition and community metabolism on the potential to buffer or exacerbate ocean acidification ${ }^{21,22}$. There is, however, incomplete knowledge of large-scale patterns of carbonate chemistry and the mechanisms controlling its variability in coastal oceans, largely due to limited observations and the added complication of dynamic regional or local processes that can be large in magnitude.

Examples of local processes that influence surface water distributions of $p \mathrm{CO}_{2}, \mathrm{pH}$, total alkalinity (TA), dissolved inorganic carbon (DIC), and $\Omega_{\text {arag }}$ in ocean margins include river and wetland inputs, coastal circulation, vertical and lateral mixing, spatial and seasonal temperature variations, the balance of biological production and respiration, and anthropogenic $\mathrm{CO}_{2}$ uptake ${ }^{23-30}$. Rivers usually carry more acidified waters with a higher DIC/TA ratio than seawater, which may weaken the ability of coastal seas to withstand anthropogenic $\mathrm{CO}_{2}$-induced acidification $^{29,31}$. Freshwater input can also suppress $\Omega_{\text {arag }}$ by reducing $\left[\mathrm{Ca}^{2+}\right]$. However, increased nutrient input from rivers may lead to elevated biological $\mathrm{CO}_{2}$ removal or basification in surface waters ${ }^{32}$, whereas the respiration of this organic material back to $\mathrm{CO}_{2}$ in bottom waters may enhance acidification at depth ${ }^{17}$. Additionally, coastal upwelling can bring low $\mathrm{pH}$ and low $\Omega_{\text {arag }}$ waters to shallow, nearshore regions and put coastal biological systems in stress ${ }^{27}$. Subsequent $\mathrm{CO}_{2}$ release to the atmosphere and biological production stimulated by the accompanying upwelled nutrients may increase $\mathrm{pH}$ and $\Omega_{\mathrm{arag}} 33$.

In addition to these driving processes, it is important to understand the influence of temperature on the spatial distributions of carbonate system properties. Coastal currents often bring waters from warm (or cold) locations to cold (or warm) locations, resulting in chemical equilibrium shifts and air-sea gas exchange, both of which are sensitive to temperature change:

$$
\begin{gathered}
\mathrm{CO}_{2 \mathrm{gas}} \stackrel{K_{0}}{\longleftrightarrow} \mathrm{CO}_{2 \mathrm{aq}}, \\
\mathrm{CO}_{2 \mathrm{aq}}+\mathrm{H}_{2} \mathrm{O}+\mathrm{CO}_{3}^{2-} \stackrel{K_{1} / K_{2}}{\longleftrightarrow} 2 \mathrm{HCO}_{3}^{-} .
\end{gathered}
$$

Here $K_{0}$ is the solubility constant, and $K_{1} / K_{2}$ is the ratio of the first and second dissociation constants of carbonic acid. When a water mass isolated from the atmosphere (referred to herein as a closed system) is cooled, the ratio, $K_{1} / K_{2}$, will increase (Fig. 1a), and the acid-base equilibrium will shift to the right to reduce dissolved $\mathrm{CO}_{2}\left(\mathrm{CO}_{2 \mathrm{aq}}\right)$ and $\mathrm{CO}_{3}^{2-}$ and increase $\mathrm{HCO}_{3}^{-}$(Eq. 2). The gas solubility constant will also increase, further reducing $p \mathrm{CO}_{2}$ following Henry's Law $\left(p \mathrm{CO}_{2}=\left[\mathrm{CO}_{2 \mathrm{aq}}\right] / K_{0}\right)($ Fig. $1 \mathrm{a}-\mathrm{c})$, as gas exchange is not allowed to compensate the cooling process in a closed system (Eq. 1). Although not explicitly shown in Eq. (2), cooling will also reduce $\left[\mathrm{H}^{+}\right]$and increase $\mathrm{pH}$ in a closed system because of the decrease in both acid dissociation constants (Fig. 1). Importantly, cooling can shift a water mass from being a source of $\mathrm{CO}_{2}$ to the atmosphere in warm, subtropical waters to a sink for $\mathrm{CO}_{2}$ in cold, mid-latitude waters when gas exchange occurs in an alongshore current. The process of cooling and gas exchange in an open-system increases $\mathrm{CO}_{2 \mathrm{aq}}$, a fraction of which combines with and reduces $\mathrm{CO}_{3}^{2-}$ and thus $\Omega_{\text {arag. }}$.

To illustrate the temperature dependences of the marine carbonate system, we define two thermodynamic end members: the closed system, with no gas exchange, and the open system, with a complete $\mathrm{CO}_{2}$ gas exchange equilibrium between seawater and the atmosphere. Thus, our theoretical framework posits that the temperature-dependent change of a species or a property in an open system is the combined effect of gas exchange caused by the solubility change and the subsequent internal thermodynamic equilibrium shift in a closed system (Fig. 1). Importantly, these two temperature effects counteract each other for $\left[\mathrm{CO}_{2 \mathrm{aq}}\right]$ (hereafter the subscript aq will be omitted), $p \mathrm{CO}_{2},\left[\mathrm{H}^{+}\right]$, and $\mathrm{pH}$, whereas they work to enhance each other for $\left[\mathrm{CO}_{3}^{2-}\right]$ and $\left[\mathrm{HCO}_{3}^{-}\right]$(or roughly DIC), with atmospheric equilibration playing the dominant role in an open system (Fig. 1). In summary, the combined result of the thermodynamic equilibrium shift and atmospheric equilibration during cooling is predicted to be an increase in $\left[\mathrm{CO}_{2}\right]$ and DIC, essentially no change in $\left[\mathrm{H}^{+}\right]$and $\mathrm{pH}$ and, by definition, no change in $\mathrm{PCO}_{2}$, and a relatively large decrease in $\left[\mathrm{CO}_{3}^{2-}\right]$ and $\Omega_{\text {arag }}$ in surface waters (Fig. 1) ${ }^{7,8,34-36}$. Therefore, spatial variations in $\mathrm{pH}$ and $\mathrm{pCO}_{2}$ largely reflect air-sea disequilibrium caused by local physical and biological processes that act more rapidly than gas exchange.

Here we report results from large-scale, regional marine carbonate chemistry observing efforts on the Atlantic, Gulf, and Pacific coasts of North America. This synthesis reveals the domain-scale and local controls on carbonate properties driven by atmospheric $\mathrm{CO}_{2}$ exchange and physical, chemical, and biological ocean processes. Our comparative study of marine carbonate chemistry across physically and biologically dissimilar ocean margins provides new insight about the mechanisms controlling $\mathrm{CO}_{2}$ parameter distributions, timescales of variability, and responses to ocean warming and acidification.

\section{Results}

The Atlantic and Gulf coasts. The North American Atlantic and Gulf of Mexico (GOM) coastal regions are characterized by broad, shallow shelves influenced on the landward side by rivers and wetlands and on the seaward side by alongshore currents. Most notably, the northbound Gulf Stream Current system brings warm, high-salinity source waters from the tropics, while the southbound Labrador Current brings cold, low-salinity source waters from the Arctic and subarctic regions (Supplementary Fig. 1) ${ }^{37-39}$. While data presented here were collected during slightly different summer months on the Atlantic coast (Supplementary Table 1), the spatial patterns of all parameters are consistent for the cruises conducted in 2007, 2012, and 2015, each plotted with a shift in longitude for the purpose of illustration (Fig. 2, Supplementary Table 2).

Sea surface temperature (SST) (Fig. 2a) and salinity (SSS) (Fig. 2b) decrease from southwest to northeast. The surface TA distribution follows that of salinity, with the highest TA values in the GOM, a sharp south-to-north decrease along the Atlantic coast $^{24,25}$, and nearshore modifications by major rivers ${ }^{40}$ (Fig. 2c). In contrast to the sharp meridional decline in TA, the DIC gradient is weak along the Atlantic coast, exhibiting smaller south- 

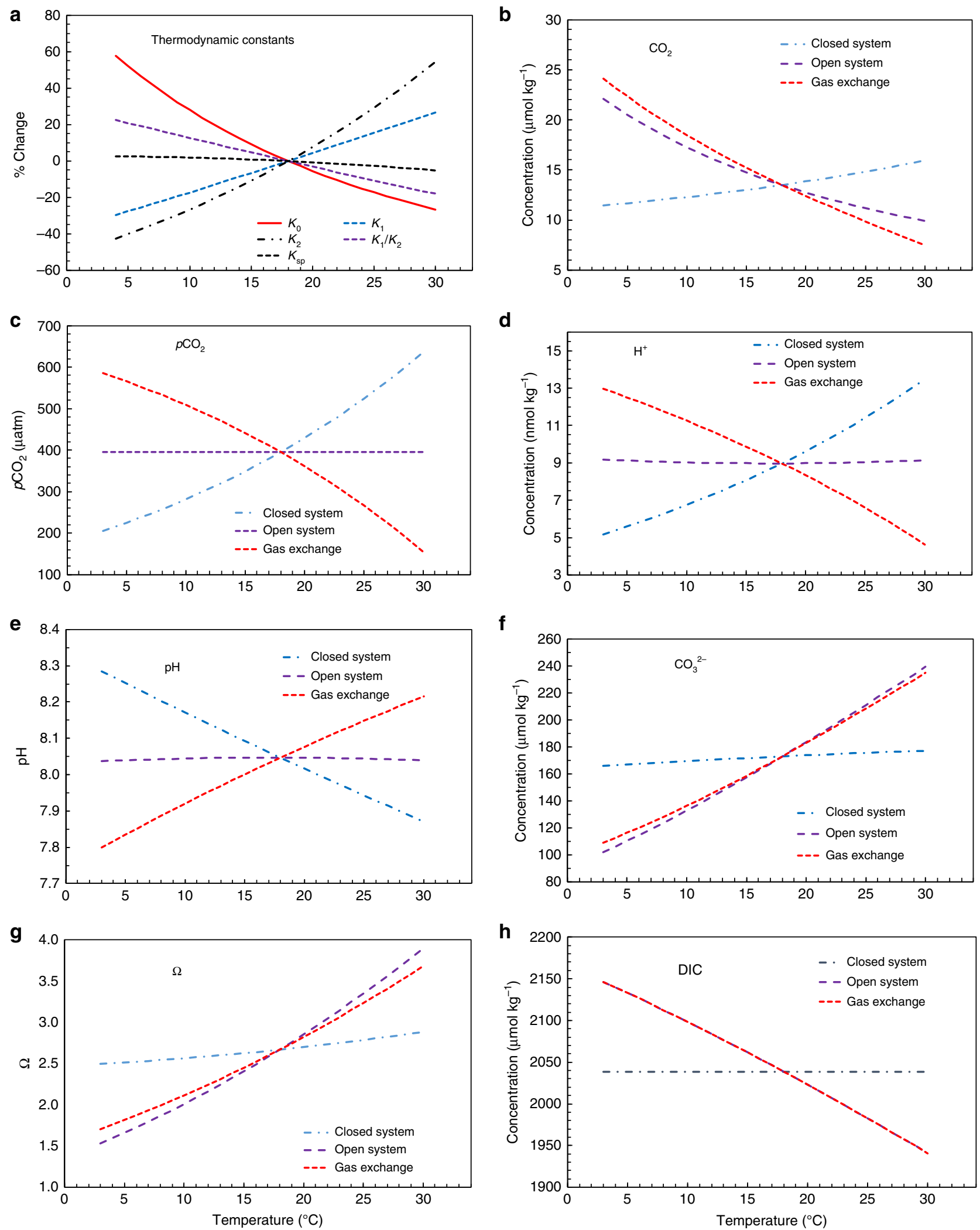

to-north decreases and some high values in the northern regions (Fig. 2d). Thus, the DIC/TA ratio increases sharply from south-tonorth (Fig. 2f), which strongly correlates with SST (Supplementary Table 3). The DIC/TA ratio is a measure of the acid-base equilibrium point of seawater, with higher ratio indicating higher $\mathrm{CO}_{2}$ fraction in the DIC pool and more acidified, less buffered

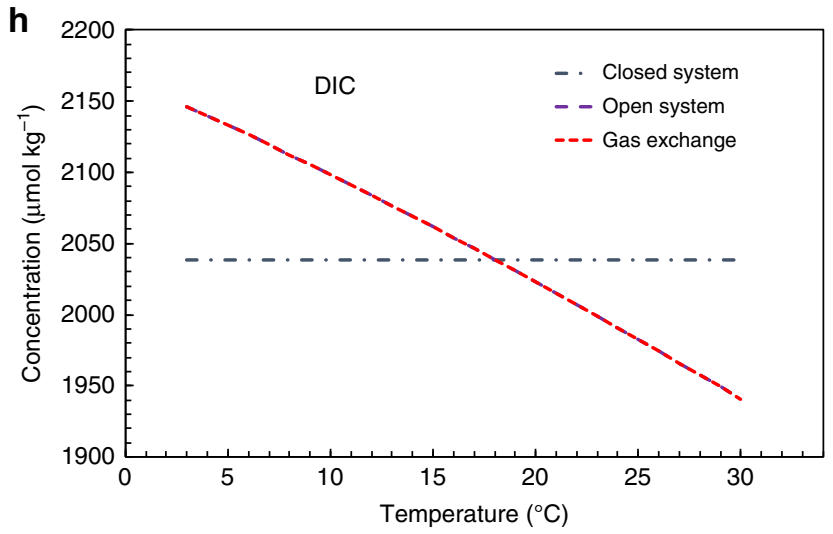

states $^{41}$. Note, while the GOM has both high DIC and TA values, its DIC/TA ratio is the lowest, indicating the least acidified state of all the North American margins. In addition, elevated TA values in North America's largest river, the Mississippi, cause the northern GOM to have one of the highest TA-to-salinity ratios $(\sim 75)$ in the world ocean (Fig. $2 \mathrm{e})^{29,36,42,43}$. 
Fig. 1 Temperature dependence of $\mathbf{C O}_{\mathbf{2}}$ system species and thermodynamic constants. a Thermodynamic constants, $\mathbf{b} \mathrm{CO}_{2}, \mathbf{c} p \mathrm{CO}_{2}$, $\mathbf{d}\left[\mathrm{H}^{+}\right]($total concentration), e pH (on the total proton scale), $\mathbf{f}\left[\mathrm{CO}_{3}^{2-}\right], \mathbf{g} \Omega_{\text {arag, }}$ and $\mathbf{h}$ DIC. Here $K_{\mathrm{o}}$ is Henry's Law constant, and, by convention, dissolved $\mathrm{CO}_{2}$ ( $99.5 \%)$ and $\mathrm{H}_{2} \mathrm{CO}_{3}(\sim 0.5 \%)$ are not differentiated and are combined as one in $\left[\mathrm{CO}_{2 \mathrm{aq}}\right]$ (or in $\left[\mathrm{H}_{2} \mathrm{CO}_{3}\right]$ ). The first acid dissociation reaction step is $\mathrm{H}_{2} \mathrm{CO}_{3}=\mathrm{H}^{+}+\mathrm{HCO}_{3}^{-}$with its equilibrium constant defined as $\mathrm{K}_{1}=\left[\mathrm{H}^{+}\right]\left[\mathrm{HCO}_{3}^{-}\right] /\left[\mathrm{H}_{2} \mathrm{CO}_{3}\right]$, whereas the second dissociation step is $\mathrm{HCO}_{3}^{-}=\mathrm{H}^{+}+\mathrm{CO}_{3}^{2-}$ with its equilibrium constant defined as $K_{2}=\left[\mathrm{H}^{+}\right]\left[\mathrm{CO}_{3}^{2-}\right] /\left[\mathrm{HCO}_{3}^{-}\right]$. A combined equilibrium constant $K_{1} / K_{2}$ is defined for the combined reaction (Eq. 2). The open system is calculated under an assumption of water in full equilibrium with the atmosphere or at a constant $p \mathrm{CO}_{2} \mathrm{condition}$ with $p \mathrm{CO}_{2}=$ $395 \mu \mathrm{atm}, \mathrm{TA}=2280 \mu \mathrm{mol} \mathrm{kg}^{-1}$, and $\mathrm{S}=35$. At $18^{\circ} \mathrm{C}$, the open system has a DIC $=2038.6 \mu \mathrm{mol} \mathrm{kg}-1$. The closed system is calculated under an assumption of no $\mathrm{CO}_{2}$ gas exchange with the atmosphere or at a constant DIC condition with TA $=2280 \mu \mathrm{mol} \mathrm{kg}{ }^{-1}, \mathrm{DIC}=2038.6 \mu \mathrm{mol} \mathrm{kg}-1$, and $\mathrm{S}=35$. For the purpose of illustrating the carbonate chemistry behavior, and for convenience, we set $18{ }^{\circ} \mathrm{C}$ as the reference point where the closed system and the open system have the same parameters. In this case, the gas exchange term $=$ open system $(T)-$ closed system $(T)+$ open system $\left(18^{\circ} \mathrm{C}\right)$, where $T$ is the temperature. Thus, the gas exchange term reflects DIC increases (or decrease) at lower (or higher) temperature by taking up $\mathrm{CO}_{2}$ from (or releasing $\mathrm{CO}_{2}$ to) the atmosphere and the redistribution of DIC among various species via acid-base equilibrium shifts.
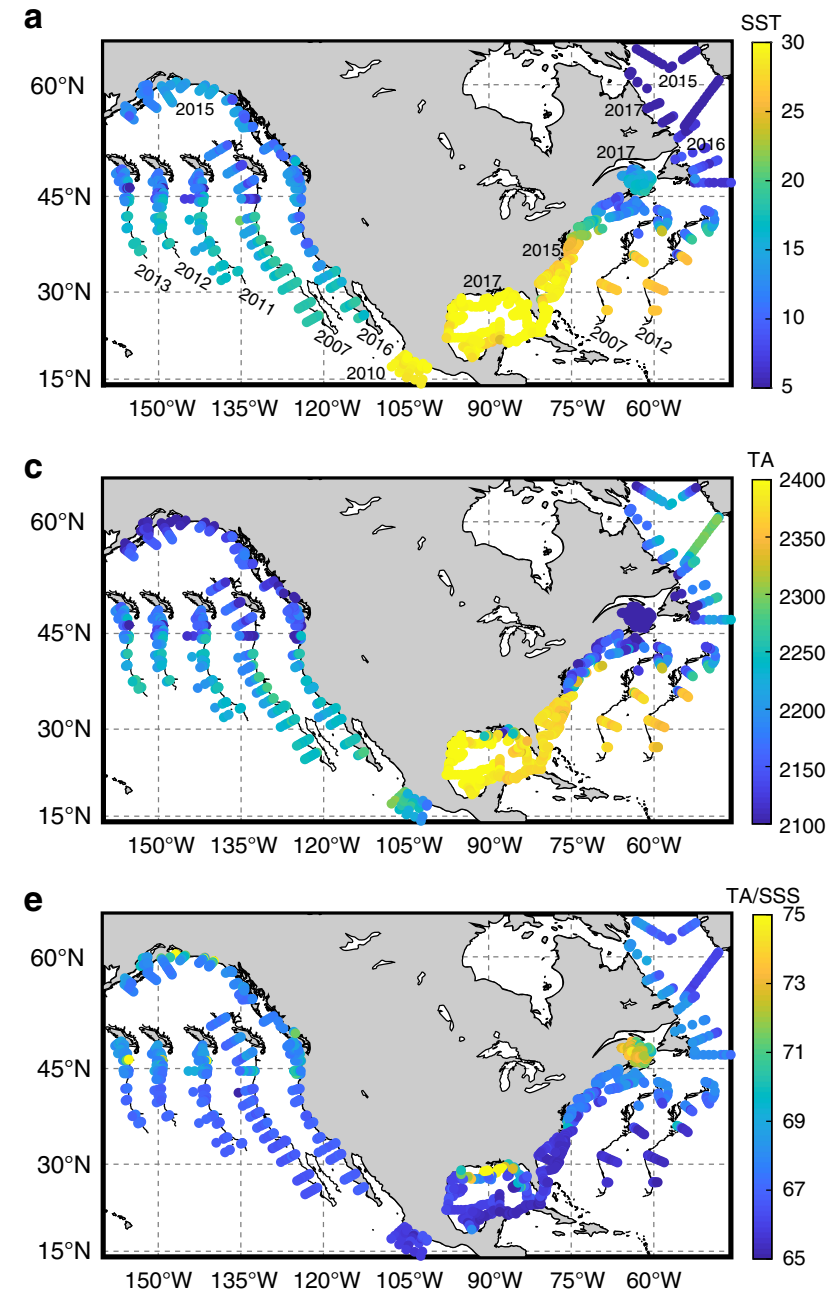
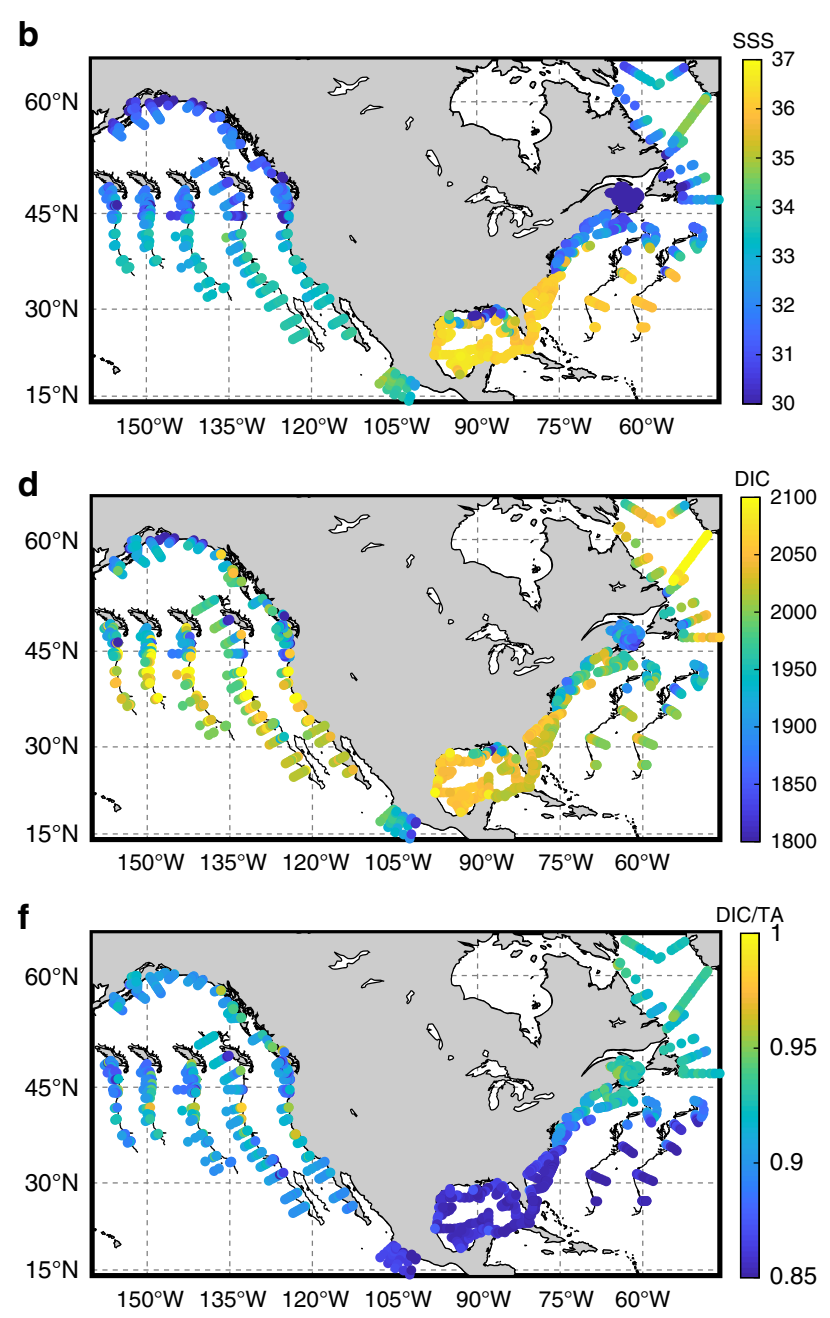

Fig. 2 Distributions of physical and biogeochemical parameters. These parameters are important to understand the marine carbonate system in surface seawater along the North American margins. a Sea surface temperature (SST), b sea surface salinity (SSS), c total alkalinity (TA), d total dissolved inorganic carbon (DIC), e TA/SSS ratio, and $\mathbf{f}$ DIC/TA ratio. See the "Methods" section for details about the measurement or calculation of these parameters. To conserve space, only the 2015-2017 data are presented in their exact geographic locations on a North American ocean margin map, while earlier data are plotted at the correct latitude with a longitude offset to show that the general patterns presented here are persistent across cruises conducted in different months and years. Cruise dates and general locations are given in the "Methods" section and Supplementary Table 2.

Sea surface $p \mathrm{CO}_{2}$ and $\mathrm{pH}$ show more complex spatial patterns (Fig. 3a, c). These parameters exhibit no significant co-variation with SST and weak (or no) co-variation with DIC/TA and the percent saturation of dissolved oxygen (DO\%) in surface waters, an indicator of biological activity (Supplementary Fig. 2 and Table 3). This is likely due to the influence of multiple competing processes along the Atlantic and GOM coasts. By normalizing the $p \mathrm{CO}_{2}$ and $\mathrm{pH}$ values to $25^{\circ} \mathrm{C}$ (i.e., setting the thermodynamic constants to $25^{\circ} \mathrm{C}$ in a closed-system calculation), a south-tonorth pattern becomes apparent with high $p \mathrm{CO}_{2 @ 25}{ }^{\circ} \mathrm{C}$ and low $\mathrm{pH}_{@ 25^{\circ} \mathrm{C}}$ values in the cold northern regions. A comparison of $\mathrm{pCO}_{2}$ and $\mathrm{pH}$ distributions at in situ SST and at $25^{\circ} \mathrm{C}$ not only reveals the important role of temperature in seawater carbonate system thermodynamic equilibrium, but, perhaps more 

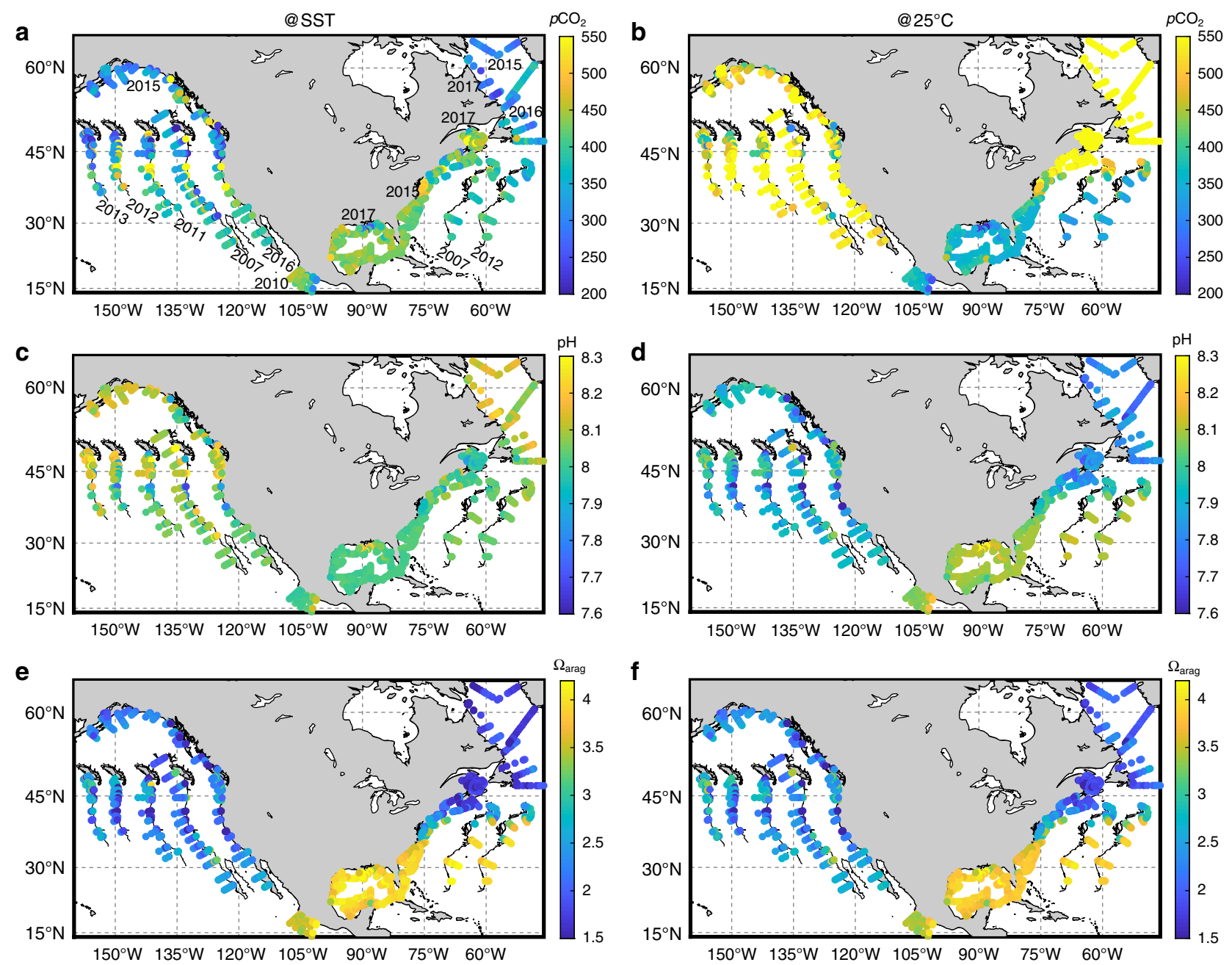

Fig. 3 Distributions of marine carbonate system parameters. Shown are parameters in surface seawater along the North American margins at field temperature and normalized to $25^{\circ} \mathrm{C}$. Left column panels are at field temperature (@SST), while the right column panels are at $25^{\circ} \mathrm{C}$. a, b Partial pressure of $\mathrm{CO}_{2}\left(\mathrm{pCO}_{2}\right), \mathbf{c}, \mathbf{d ~ p H}$ (on the total scale), and $\mathbf{e}, \mathbf{f}$ aragonite saturation state $\left(\Omega_{\text {arag }}\right)$. Note that the temperature normalization from field $\mathrm{SST}$ to $25^{\circ} \mathrm{C}$ is performed under the assumption of a closed system with no gas exchange between surface seawater and the atmosphere (thus no DIC change). As in Fig. 2, only the most recent data are presented in their exact geographic locations, while earlier data are plotted at the correct latitude with a longitude offset.

importantly, also the role of gas exchange in eliminating the temperature-induced air-sea disequilibrium. In other words, high DIC/TA exists in cold northern waters mainly due to atmospheric $\mathrm{CO}_{2}$ uptake induced by low SST. In mid-latitude regions, low observed $p \mathrm{CO}_{2}$ and high observed $\mathrm{pH}$ appear in areas of high DO $\%$, suggesting biological $\mathrm{CO}_{2}$ removal there (e.g., early summer in the Gulf of Maine, Fig. 3 and Supplementary Fig. 2$)^{44}$.

In northern GOM coastal waters, low $\mathrm{pCO}_{2}$ and high $\mathrm{pH}$ values (at both SST and $25^{\circ} \mathrm{C}$, Fig. 3a-d) strongly correlate with the low salinity, high DO\%, and low DIC/TA ratios in the nutrient-rich Mississippi River plume-influenced region, revealing the importance of local biological $\mathrm{CO}_{2}$ removal driven by riverine nutrients (Supplementary Table 3). The rest of the GOM has relatively high $p \mathrm{CO}_{2}$ and low $\mathrm{pH}$, reflecting the warm climate and low biological production in offshore waters ${ }^{42}$. Carbonate precipitation is another process that could be contributing to the relatively high $p \mathrm{CO}_{2}$ and low $\mathrm{pH}$ conditions. This is supported by a slightly lower TA/SSS ratio (Fig. 2e) and a higher DIC/TA ratio (Fig. 2f, Supplementary Fig. 4) in southern GOM, indicating more TA removal than DIC removal. Precipitation likely occurs in waters above $\mathrm{CaCO}_{3}$-rich banks at the Florida Keys and Yucatan peninsula, but can also happen in other areas ${ }^{45}$.

Most strikingly, along the entire Atlantic and GOM coasts, the large-scale spatial distribution of $\Omega_{\mathrm{arag}}$, an important metric for ocean acidification stress on organisms, bears little resemblance to the distributions of $p \mathrm{CO}_{2}$ and $\mathrm{pH}$ (Fig. 3). Rather, the $\Omega_{\mathrm{arag}}$ distribution is similar to SST and is inversely correlated with the DIC/TA ratio $(r=-0.996, p<0.001$ in the Atlantic, see Supplementary Table 3 for other margins). Thus, similar to the strong DIC/TA and temperature gradients, there is a strong south-to-north decline in $\Omega_{\mathrm{arag}}$. Interestingly, $\Omega_{\mathrm{arag}}$ and its associated parameters (e.g., $\left[\mathrm{CO}_{3}^{2-}\right]$, Supplementary Fig. 3), but not $p \mathrm{CO}_{2}$ and $\mathrm{pH}$, change abruptly at Cape Hatteras, where the Gulf Stream moves offshore and the influence of the Labrador Current increases in coastal waters. The highest $\Omega_{\text {arag }}$ appears in the GOM, which is consistent with the existence of the highest SST and TA and lowest DIC/TA ratio there. Strong biological $\mathrm{CO}_{2}$ removal in the Mississippi River plume also contributes to low DIC/TA ratio and high $\Omega_{\text {arag }}$ values in local surface waters ${ }^{42}$. Finally, distinct from $p \mathrm{CO}_{2}$ and $\mathrm{pH}$, temperature-normalizing 
$\Omega_{\text {arag }}$ does not alter the south-to-north spatial pattern in the Atlantic and GOM coasts (Fig. 3f).

The California Current System. The California Current System (CCS) extends from roughly the US-Canadian border to Baja California and is characterized by narrow shelves with strong, cold equatorward alongshore currents, and wind-driven upwelling events from late spring to early fall (Supplementary Fig. 1) ${ }^{46-48}$. While upwelling strength may vary, the observed carbonate chemical patterns are largely consistent (2007 and 2016 data were collected in late spring, while 2011, 2012, and 2013 data were collected in late summer) (Figs. 2 and 3). Here, similar to SSS, TA shows a weak south-to-north-decreasing gradient (Supplementary Table 3), while DIC has only a slightly stronger south-to-north-decreasing gradient ${ }^{46}$. As a result, there is no coherent meridional gradient in the DIC/TA ratio, reflecting different mechanisms at play from those along the Atlantic and Gulf coasts. However, higher $p \mathrm{CO}_{2}$ and lower $\mathrm{pH}$ values are generally observed in the south.

As reported previously, $p \mathrm{CO}_{2}$ is high and $\mathrm{pH}$ is low near

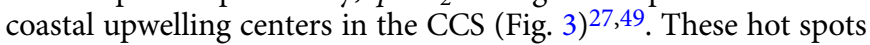
are caused by the strong upwelling of subsurface waters with high DIC/TA ratios and low $\mathrm{O}_{2}, \mathrm{pH}$, and $\Omega_{\text {arag }}$ values caused by biological respiration and anthropogenic $\mathrm{CO}_{2}$ (Supplementary Fig. 5 and Table 3$)^{27,47}$. An interesting characteristic of the CCS, offshore of the immediate upwelling centers, is that $p \mathrm{CO}_{2}$ is generally lower and $\mathrm{pH}$ is higher relative to the Atlantic and GOM coasts at similar latitudes. This is mainly a result of the strong biological compensation following upwelling and incomplete compensation by air-sea gas exchange in the CCS as shown by field observations ${ }^{49}$ and a numerical model ${ }^{47}$. However, once the temperature is normalized to $25^{\circ} \mathrm{C}$, such CCS vs. Atlantic contrasts largely disappear (Fig. 3). This reflects the important role of low SST values in keeping $p \mathrm{CO}_{2}$ low and $\mathrm{pH}$ high via thermodynamic equilibrium shift and in maintaining a significant air-sea disequilibrium. In contrast, $\Omega_{\text {arag }}$ is almost ubiquitously low along the entire CCS coast relative to the GOM and southern Atlantic margins. It is particularly notable that, distinct from $p \mathrm{CO}_{2}$ and $\mathrm{pH}$, normalization to $25^{\circ} \mathrm{C}$ does not alter this $\Omega_{\mathrm{arag}}$ contrast between the West and East Coasts. Low SST in the CCS allows more $\mathrm{CO}_{2}$ to be retained in the $\mathrm{CO}_{2}$-rich upwelling waters due to a greater gas solubility, which keeps $\left[\mathrm{CO}_{3}^{2-}\right]$ low (Eq. 1). Thus, the seemingly paradoxical co-existence of relatively high $\mathrm{pH}$ and low $\Omega_{\text {arag }}$ in the CCS reflects the distinct sensitivities of these parameters to thermodynamic constants, gas exchange, mixing, and biological processes.

Other Pacific coastal regions. The Gulf of Alaska has the widest continental shelves on the Pacific coast and is characterized by poleward winds and downwelling surface circulation during summer months $s^{50}$. Sea surface $p \mathrm{CO}_{2}$ is low and $\mathrm{pH}$ is high in these relatively high-latitude, cold waters (Fig. 3), while $\Omega_{\text {arag }}$ is ubiquitously low. In Mexican Pacific coastal waters, south of the Gulf of California, SST is particularly high, while SSS and TA are similar to its northern neighbor (the CCS) ${ }^{51}$. Here, $p \mathrm{CO}_{2}$ and $\mathrm{pH}$ values generally align with the weak south-to-north trends of Pacific coastal waters; however, DIC and DIC/TA are notably lower and $\Omega_{\text {arag }}$ is much higher than the waters to the north (Figs. 2 and 3).

The Revelle factor distributions. The capacity of seawater to resist a change in its acid-base properties in response to a DIC perturbation caused by $\mathrm{CO}_{2}$ uptake from the atmosphere, or other processes, is important when considering the impacts of ocean acidification ${ }^{9,10,52,53}$. The characteristics of how each carbonate system species will respond to such a disturbance can be described with a set of buffer factors ${ }^{41,54,55}$. Among them, the Revelle factor (RF) is most often used,

$$
\mathrm{RF}=\frac{\Delta p \mathrm{CO}_{2}}{p \mathrm{CO}_{2}} / \frac{\Delta \mathrm{DIC}}{\mathrm{DIC}}
$$

which is the fractional change of the $\mathrm{CO}_{2}$ species to a fractional DIC change at constant SST, SSS, and TA. A lower RF indicates a greater buffer capacity and a lower sensitivity of seawater $p \mathrm{CO}_{2}$ to changes in DIC.

Spatial distributions of RF (Fig. 4a) show clear meridional gradients along the Atlantic margin, but no such pattern in the CCS. This suggests that the most buffered waters are in the GOM, southern US East Coast, and Mexican Pacific coast. The least buffered waters, which may be most sensitive to increasing ocean carbon content, are in the CCS upwelling centers and the mid to northern Atlantic waters of our study domain. In other words, the change in $p \mathrm{CO}_{2}, \mathrm{pH}$, and $\Omega_{\text {arag }}$ per unit DIC increase will be larger in the upwelling-dominated CCS waters and northern Atlantic waters than in other coastal waters of the North American margin. However, next to upwelled waters with characteristically high RF in the CCS, strong biological removal of $\mathrm{CO}_{2}$ substantially increases the buffer capacity as indicated by the low RF values associated with high $\mathrm{DO} \%$ and low nitrate at around $12{ }^{\circ} \mathrm{C}$ in Fig. $4 \mathrm{c}$, d.

The spatial patterns of RF are similar and closely correlated to $\left[\mathrm{CO}_{3}^{2-}\right]$ and $\Omega_{\text {arag }}$ (Figs. 3e, $4 \mathrm{a}, \mathrm{b}$ and Supplementary Fig. 3 and Table 3), supporting the notion that the $\mathrm{CO}_{3}^{2-}$ concentration plays a critical role in the ability to resist acidification as added anthropogenic or respiratory $\mathrm{CO}_{2}$ is largely neutralized by $\mathrm{CO}_{3}^{2-}$ to form $\mathrm{HCO}_{3}^{-}$(Eq. 2). Thus, $\left[\mathrm{CO}_{3}^{2-}\right], \Omega_{\text {arag }}$ and inversely the DIC/TA ratio (Fig. $2 \mathrm{f}$ ) are good proxies or easy-to-understand surrogates for seawater buffer capacity. In all North American margin waters, the DIC/TA ratio is inversely correlated with $\left[\mathrm{CO}_{3}^{2-}\right]$ and $\Omega_{\text {arag }}$ (Supplementary Table 3). In seawater, the point at which DIC/TA $\approx 1$ (or DIC $\approx$ TA) represents the most sensitive state of the system to $\mathrm{CO}_{2}$ addition because, at this point, $\left[\mathrm{CO}_{2}\right] \approx\left[\mathrm{CO}_{3}^{2-}\right]$ and $\mathrm{pH}=-0.5 \log \left(K_{1} K_{2}\right)-0.5 \log \left(\left[\mathrm{CO}_{2}\right] /\right.$ $\left.\left[\mathrm{CO}_{3}^{2-}\right]\right)$ changes the fastest ${ }^{17}$. Also note that this point $(\mathrm{pH} \approx$ $\left.-0.5 \log \left(K_{1} K_{2}\right)\right)$ occurs at a higher $\mathrm{pH}$ in cold waters $\left(7.71\right.$ at $3^{\circ} \mathrm{C}$ and 7.60 at $\left.10^{\circ} \mathrm{C}\right)$ than in warm waters $\left(7.35\right.$ at $\left.30^{\circ} \mathrm{C}\right)$ (Supplementary Fig. 6), making cold waters more sensitive to $\mathrm{CO}_{2}$ addition ${ }^{56}$. The cold waters of the northeastern margins, Alaskan shelf, and the CCS upwelling centers are approaching this point and are thus most vulnerable to ocean acidification.

Continental-scale pattern vs. local variability. To explore the first-order controlling mechanisms on large-scale spatial patterns of carbonate chemistry parameters on contrasting margins, we first compare field-observed DIC, $p \mathrm{CO}_{2}, \mathrm{pH}$, and $\Omega_{\text {arag }}$ distributions with those predicted from gas equilibrium with atmospheric $\mathrm{CO}_{2}$. We do this by calculating each of these parameters from SST, SSS, and TA under the assumption of sea surface $\mathrm{CO}_{2}$ gas equilibrium with the atmosphere. Over a large latitudinal range involving multiple water masses along the North American Atlantic and GOM coasts, DIC and $\Omega_{\text {arag }}$ generally follow air-sea gas equilibrium-based predictions on a seasonal timescale (months) (Fig. 5a, b, e, f). This atmospheric $\mathrm{CO}_{2}$ equilibrium control mechanism would dictate a relatively high DIC and low $\Omega_{\text {arag }}$ in cold northern waters, where $\mathrm{CO}_{2}$ solubility is high and the acid-base equilibrium favors the neutralization of $\mathrm{CO}_{2}$ and $\mathrm{CO}_{3}^{2-}$ to $\mathrm{HCO}_{3}^{-}$(Eqs. 1 and 2; Fig. 1a). In contrast, relatively low DIC and high $\Omega_{\text {arag }}$ conditions would occur in warmer southern waters, where $\mathrm{CO}_{2}$ solubility and $K_{1} / \mathrm{K}_{2}$ are lower, favoring $\mathrm{HCO}_{3}^{-}$dissociation to $\mathrm{CO}_{2}$ and $\mathrm{CO}_{3}^{2-}$ with $\mathrm{CO}_{2}$ degassing to the 
a

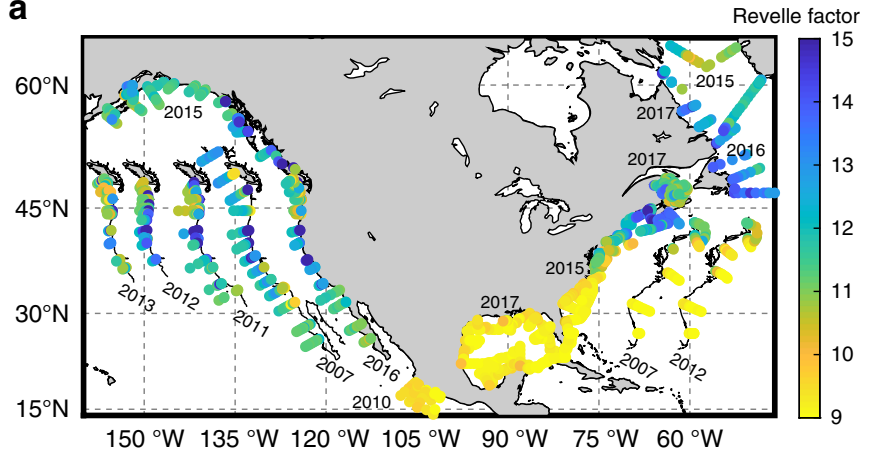

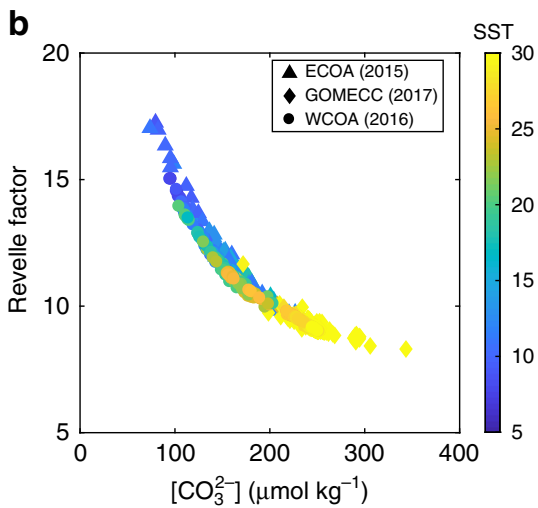

c

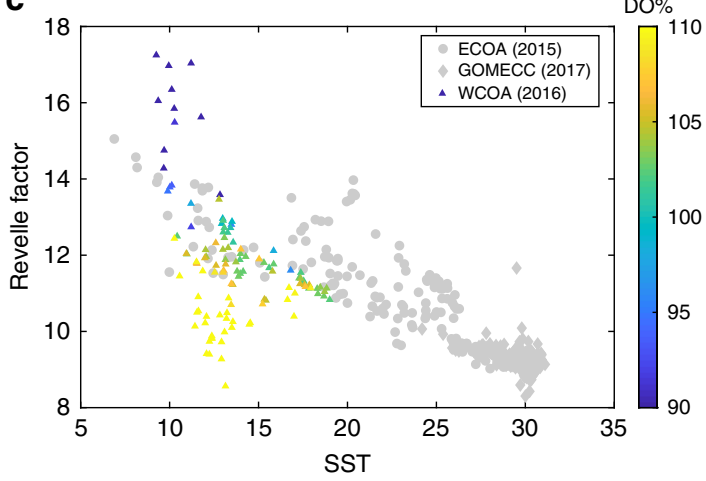

d

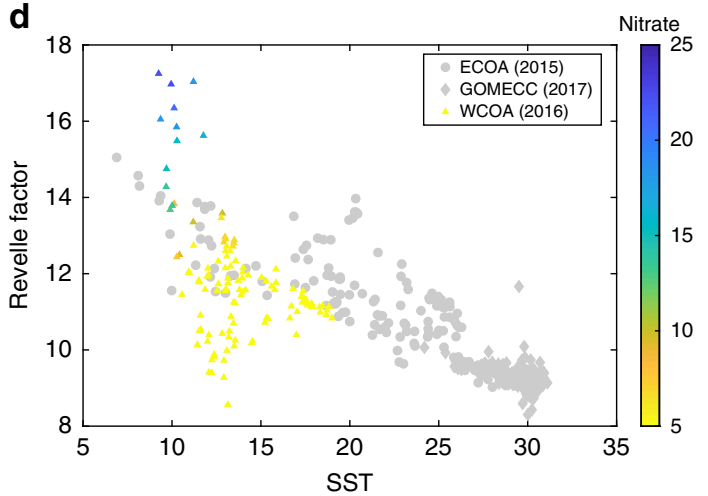

Fig. 4 Revelle factor in the North Atlantic margins. a Spatial distribution of the Revelle factor, b correlation of the Revelle factor to [CO ${ }_{3}^{2-}$, and c, $\mathbf{d}$ correlation of the Revelle factor to SST color coded by $\mathrm{DO} \%$ and $\left[\mathrm{NO}_{3}^{-}\right]$. Spatial distribution of [CO $\left.{ }_{3}^{2-}\right]$ is presented in Supplementary Fig. 4 . In c, d, only the CCS data are color coded.

atmosphere. Such distribution patterns are known in global openocean basins ${ }^{5-7,36,57}$ but have not been reported before in more dynamic coastal oceans. The fact that the DIC/TA ratio is lowest in the GOM and highest in northern Atlantic coastal waters reflects the temperature-regulated gas equilibrium and acid-base equilibrium shift. The observations of particularly low DIC/TA ratio and high $\Omega_{\text {arag }}$ in the Mexican Pacific margin (Figs. $2 \mathrm{f}$ and 3e) further support the argument made here that air-sea gas equilibrium largely controls DIC and $\Omega_{\text {arag }}$ in surface waters. This is true even in the region that is located right above the North Eastern Tropical Pacific $\left(15-20^{\circ} \mathrm{N}, 100-110^{\circ} \mathrm{W}\right)$ oxygen minimum zone with elevated DIC concentrations of $2200 \mu \mathrm{mol} \mathrm{kg}{ }^{-1}$ at a depth of only $50 \mathrm{~m}$ (ref. ${ }^{51}$ ). To the north in the Gulf of Alaska, however, slightly lower DIC and higher $\Omega_{\text {arag }}$ than predicted from atmospheric equilibration are likely due to legacy effects of strong biological $\mathrm{CO}_{2}$ removal in late spring and early summer (Fig. $5 \mathrm{c})^{50}$.

Along the CCS, however, while atmospheric equilibrium still exerts strong control on DIC, upwelling and subsequent biological utilization of $\mathrm{CO}_{2}$ have greatly modified the DIC concentrations in coastal waters. These processes have variable timescales of days to weeks ${ }^{46,47,49}$ and are much less than the timescales of gas equilibration (one to a few months). The association of a positive DIC deviation with low temperature and high nutrients, a sign of upwelling (Fig. $5 c, d$ ), confirms that the source of DIC is from $\mathrm{CO}_{2}$-rich subsurface waters that have been upwelled in the CCS. The impact of upwelling and biology becomes greater for $\Omega_{\text {arag, }}$ which deviates substantially from the atmospheric equilibrium-based prediction in the CCS (Fig. 5g, h).

Despite the strong role of air-sea gas exchange, observed $\mathrm{pH}$ and $p \mathrm{CO}_{2}$ values can deviate greatly from those at atmospheric equilibrium even in the Atlantic and GOM coasts (Fig. 5i, j, m, n). This is particularly true in the CCS where strong upwelling (high nutrient) or biological production (low nutrient) lead to extreme $\mathrm{pH}$ and $p \mathrm{CO}_{2}$ values, whereas the expected $\mathrm{pH}$ and $p \mathrm{CO}_{2}$ from the atmospheric equilibrium are nearly invariable (Fig. 5k, l, o, p). Deviations of DIC, $\Omega_{\text {arag, and }} \mathrm{pH}$ from gas equilibration are highly correlated with positive or negative deviations of seawater $p \mathrm{CO}_{2}$ from atmospheric $p \mathrm{CO}_{2}$ on all margins (Supplementary Fig. 7). In the CCS, the positive deviation in DIC and negative deviations in $\Omega_{\text {arag }}$ and $\mathrm{pH}$ are associated with $\mathrm{CO}_{2}$ supersaturation induced by the upwelling of $\mathrm{CO}_{2}$-rich subsurface waters, while the opposite conditions ( $\mathrm{CO}_{2}$ undersaturation) are associated with the subsequent stimulation of biological production $^{27,47}$. In the GOM, such deviations are controlled by biological $\mathrm{CO}_{2}$ removal in the low-salinity river plume and net respiration and $\mathrm{CaCO}_{3}$ precipitation in the high-salinity waters. On the Atlantic coast, a combination of temperature changes associated with physical transport by large-scale alongshore currents, biological $\mathrm{CO}_{2}$ removal, and local terrestrial exports are all at play (Supplementary Fig. 7).

Sensitivity of carbonate chemistry to perturbations. A fundamental question to ask is why do DIC and $\Omega_{\text {arag }}$ generally follow air-sea gas equilibrium-based predictions in the Atlantic and Gulf coasts, while $\mathrm{pH}$ and $p \mathrm{CO}_{2}$ distributions are decoupled from the atmospheric equilibrium and are most sensitive to local physical and biological modifications? We contend that this is mainly the result of two factors. First and most importantly, the temperature effect on carbonate chemistry has two components, one is the internal effect on the thermodynamic equilibrium constants, including the acid-base dissociation constants $K_{1}$ and $K_{2}$ and the solubility constant $K_{0}$ under no gas exchange conditions, while the other is the external effect related to DIC concentration changes caused by gas exchange. As shown in Fig. 1, in an open 


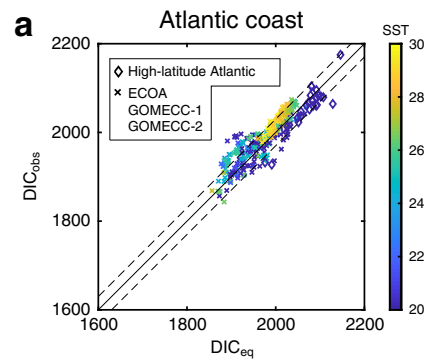

e

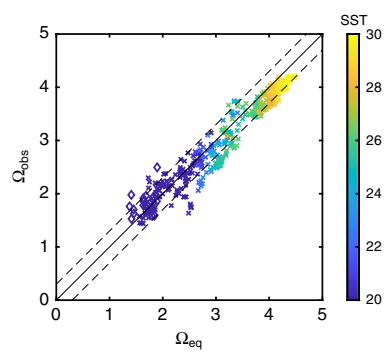

i
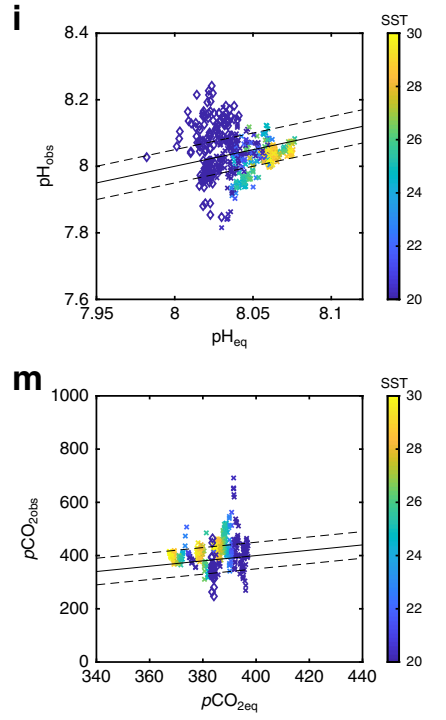

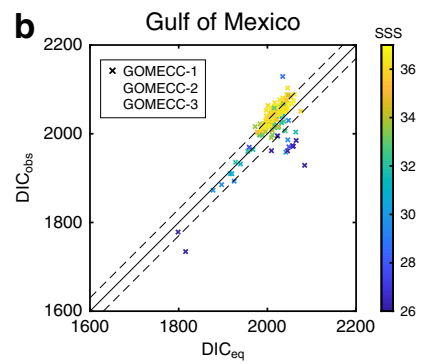

f
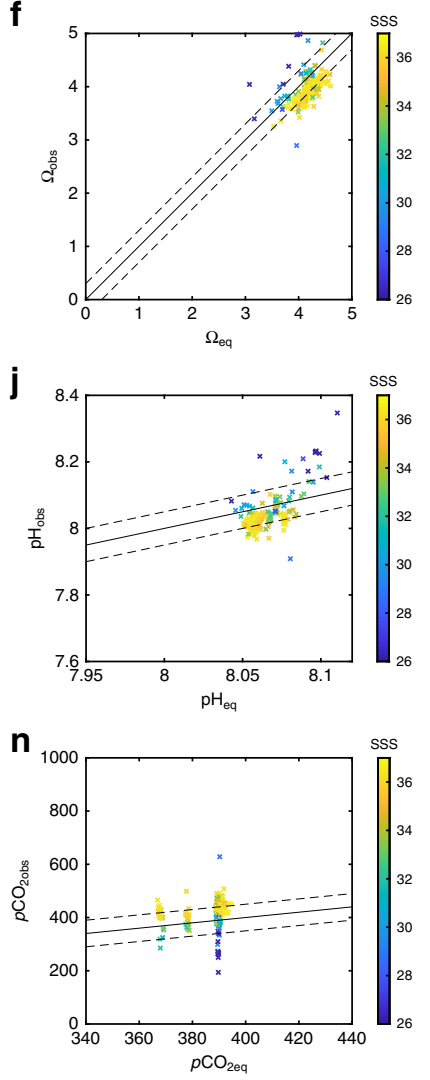
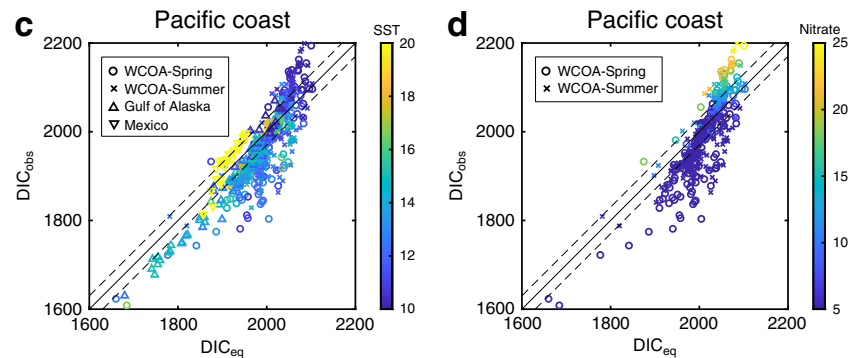

g

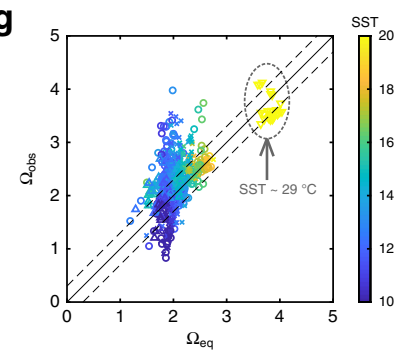

h
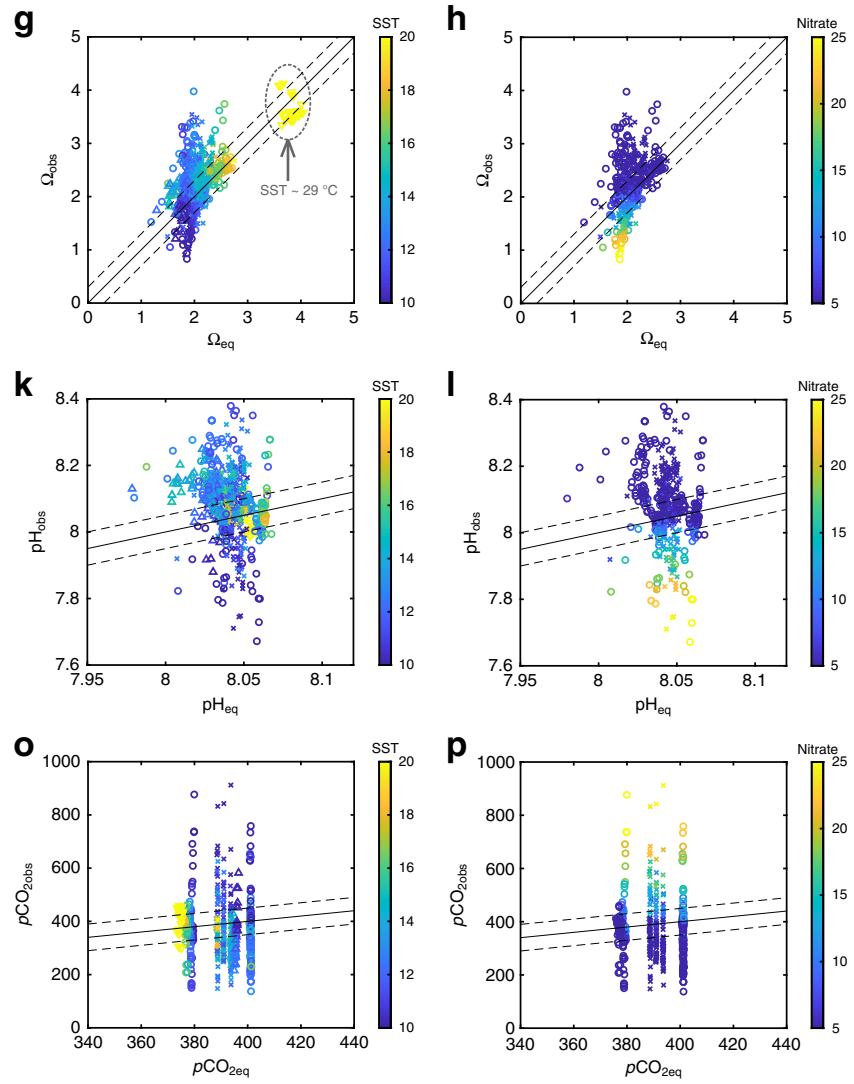

Fig. 5 Observations vs. calculated values. These values are at equilibrium with atmospheric $\mathrm{CO}_{2}$ along $\mathrm{North}$ American margins. a-d are $\mathrm{DIC}$, e-h are $\Omega_{\text {arag, }} \mathbf{i}-\mathbf{I}$ are $\mathrm{pH}, \mathbf{m}-\mathbf{p}$ are $\mathrm{pCO}_{2}$ in the Atlantic Coast (column 1), Gulf of Mexico (column 2), and Pacific Coast (columns 3 and 4 ). The Pacific Coast occupies two columns color coded by SST and Nitrate, respectively. DIC obs, $\Omega_{\text {obs, }} \mathrm{pH}_{\text {obs, }}$ and pCO ${ }_{2 \text { obs }}$ stand for the measured DIC and properties calculated

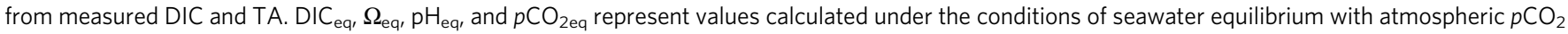

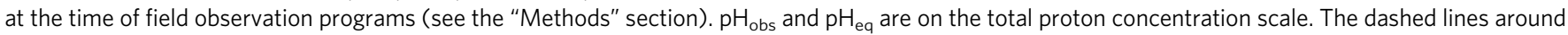
the $1: 1$ line are $\pm 30 \mu \mathrm{mol} \mathrm{kg}{ }^{-1}$ for $\mathrm{DIC}, \pm 0.3$ for $\Omega, \pm 0.05$ for $\mathrm{pH}$, and $\pm 50 \mu$ atm for $p \mathrm{CO}_{2}$.

system these two temperature effects tend to cancel each other out completely for $\mathrm{pH}$ and $p \mathrm{CO}_{2}$ and partially for $\left[\mathrm{CO}_{2}\right]$, but have an additive effect for $\left[\mathrm{CO}_{3}^{2-}\right]$, DIC, and $\Omega_{\text {arag, with the gas }}$ equilibrium playing the dominant role. Thus, moderate carbonate system perturbations caused by local physical and biological processes are essentially overshadowed for DIC and $\Omega_{\text {arag }}$ due to their large latitudinal gradients along the Atlantic and GOM margins associated with the south-to-north temperature gradient, but are apparent for $\mathrm{pH}$ and $\mathrm{pCO}_{2}$, which have no clear meridional trends. The contrasting temperature effects are also compounded by the fact that physical and biological addition and removal of DIC act linearly, while their impacts on $\mathrm{pCO}_{2}$ changes are non-linear. Second, while the internal temperature effect and upwelling of high DIC subsurface waters are essentially instantaneous or of short timescale, air-sea gas exchange compensates carbonate chemistry changes over monthly timescales. As a result, slow-acting surface processes such as cooling in poleward-moving currents along the Atlantic coast are largely compensated and appear to have relatively small impacts on surface seawater carbonate chemistry. The processes that contribute most visibly to carbonate chemistry, in particular $p \mathrm{CO}_{2}$ and $\mathrm{pH}$ variability, are those that act much faster than the timescales of gas equilibrium (e.g., upwelling, river input, and primary production, which lack SST-related meridional trends) ${ }^{36}$.

These factors also contribute to the observed sensitivity differences of $\mathrm{pH}$ and $\Omega_{\text {arag }}$ to anthropogenic, physical, and biological processes in the CCS upwelling waters. In these waters, excess $\mathrm{CO}_{2}$ relative to $\mathrm{CO}_{2}$ expected from equilibration with a preindustrial atmosphere comes from both subsurface organic carbon respiration and anthropogenic $\mathrm{CO}_{2}$ obtained when subsurface water masses were previously in contact with the atmosphere. These sources can combine to create seawater that greatly exceeds even the anthropogenically elevated modern atmospheric $p \mathrm{CO}_{2}$ and cause $\mathrm{pH}$ and $\Omega_{\text {arag }}$ in the newly upwelled waters to be much lower than they would be at atmospheric equilibrium (Supplementary Fig. 7). Subsequent $\mathrm{CO}_{2}$ degassing 
and biological blooms can reduce $\mathrm{CO}_{2}$ and increase $\mathrm{pH}$ and $\Omega_{\mathrm{arag}}$. A very strong correlation between DO and $\Omega_{\mathrm{arag}}$ in the CCS (Supplementary Table 3a) suggests that biological drawdown of DIC and upwelling of waters rich in respired DIC together overpower the influence of the small latitudinal SST-gradient in this region. However, generally lower temperatures in the CCS (compared to the GOM and south Atlantic regions) and incomplete compensation by gas exchange allow these waters to simultaneously have relatively high $\mathrm{pH}$ but low $\Omega_{\text {arag }}$ because the effects of low temperature outweigh the impacts of biological $\mathrm{CO}_{2}$ removal for $\Omega_{\text {arag }}$ but not for $\mathrm{pH}$ (Supplementary Fig. 8). The same discussion applies to high-latitude waters in the Labrador Sea in the Atlantic and Gulf of Alaska in the Pacific all have high $\mathrm{pH}$ but low $\Omega_{\mathrm{arag}}$, although in these places, the main driver for a low $\Omega_{\text {arag }}$ is the high $\mathrm{CO}_{2}$ solubility at low SSTs and the main driver for a high $\mathrm{pH}$ is the biological $\mathrm{CO}_{2}$ removal.

Timescales of coastal ocean processes. To support the conclusions derived from the field data and first principle-based analysis and to further explore the different responses of carbonate parameters to atmospheric forcing and local physical and biological processes, we simulated seasonal changes in carbonate chemistry using a time-variable box model for the Atlantic coast. The model simulates carbonate parameter changes and the associated gas exchange flux in an idealized surface mixed layer following prescribed time series of salinity, temperature, wind, biological production, and vertical exchange with the subsurface water (see details in the "Methods" section). In the northeastern margin, SST follows a typical seasonal cycle, while SSS is high in winter and decreases to a minimum in summer as a result of changing river discharge and meltwater supply ${ }^{37}$ (Fig. 6a). As expected, surface water $p \mathrm{CO}_{2}$ increases and $\mathrm{pH}$ decreases from spring to summer following the seasonal warming and display opposite behavior from summer to fall following cooling (Fig. 6b). This thermal seasonality is enhanced by high riverine $\mathrm{CO}_{2}$ export and reduced by spring biological blooms $s^{35}$. The $p \mathrm{CO}_{2}$ decrease and $\mathrm{pH}$ increase in the summer to fall cooling period are also enhanced by biological blooms and decreased river discharge. In the meantime, in contrast, DIC increases toward winter and decreases toward summer, whereas $\Omega_{\text {arag }}$ decreases toward winter and increases toward summer (Fig. 6c).

For comparison with the box model simulation, we also calculate carbonate system parameters while assuming instantaneous equilibrium between sea surface $p \mathrm{CO}_{2}$ and the atmosphere (open system conditions). The full-model Atlantic margin $p \mathrm{CO}_{2}$ and $\mathrm{pH}$ values completely decouple from the values expected from atmospheric equilibrium, but track water mass property changes associated with seasonal temperature variations and short-term local physical and biological processes. Note that the equilibrium values exhibit a much smaller range of $p \mathrm{CO}_{2}$ and $\mathrm{pH}$ variability due to cancellation of the two temperature effects under the imposed conditions where gas exchange is instantaneous (Fig. 1 and Fig. 6b, d, e). In contrast, the modeled DIC and $\Omega_{\text {arag values approximately }}$ track those predicted by instantaneous equilibrium with atmospheric $\mathrm{CO}_{2}$, although with a time lag of 1-2 months. Here a seasonal DIC maximum and $\Omega_{\text {arag }}$ minimum occur during winter when $\mathrm{CO}_{2}$ solubility is the highest with opposing results found during summer (Fig. 6c, f, g). These modelderived behaviors are consistent with the field observations and our mechanistic interpretation of them; although seasonal SST variations are used to illustrate the carbonate chemistry behaviors in the simple box model, latitudinal SST variations are reflected in the summertime observations along the Atlantic and Gulf coasts.
Interestingly, modeled $\mathrm{pCO}_{2}$ and $\mathrm{pH}$ values also show the high-frequency signals of SST and SSS variations caused by local short-term processes reflected in SST and SSS changes. In contrast, the impacts of high-frequency local processes are largely absent in the modeled DIC and greatly dampened in modeled $\Omega_{\text {arag }}$ values (Fig. 6). When a disturbance (vertical mixing with high DIC subsurface water) is introduced (with a sudden increase of DIC), with all other conditions unchanged, the $e$-folding time of $\mathrm{CO}_{2}$ system restoration (that is the disturbance is reduced to $1 / e$ or $37 \%$ of the initial value) due to degassing varies from 10 days at very high gas exchange rates (to mimic an instantaneous gas equilibration) to more than 100 days at low gas exchange rates (approaching a closed system) with $\sim 1$ month at an average wind condition and typical mixed-layer depths (Supplementary Fig. 9). In general, two to three $e$-folding intervals are needed for a disturbed signal to be completely erased. Increases in the associated nutrient input, and thus net biological production, will have an opposite effect and speed up the restoration (not shown). Thus the very different carbonate chemistry behaviors reported in this work reflect timescales of physical, chemical, and biological processes differ from instantaneous thermodynamic equilibrium, including rapid local physical processes (upwelling, mixing, etc.) acting on timescales of days to weeks, biological production (weeks), alongshore current transport (months), gas exchange processes (months to seasonal), and the seasonal thermal cycle.

\section{Discussion}

Our study illustrates that, as in the open ocean, the large-scale meridional gradient in surface water temperature regulates $\mathrm{CO}_{2}$ gas equilibration with the atmosphere and plays a first-order role in determining the spatial distributions of DIC and $\Omega_{\text {arag }}$ on seasonal timescales in non-upwelling-dominated ocean margins. In contrast, $p \mathrm{CO}_{2}$ and $\mathrm{pH}$ variations are more reflective of shortterm, local modifications by coastal ocean physical and biological processes. In upwelling-dominated regions along eastern boundary current ocean margins, however, the atmospheric $\mathrm{CO}_{2}$ equilibrium mechanism is perturbed much more than that along other ocean margins and in the open ocean $5,6,8,36,58$. This is because dynamic coastal conditions further accentuate the contrasts between longer timescale air-sea equilibrium in slowly moving coastal currents and modifications by short-term, local physical and biological processes. As such, the two commonly used ocean acidification metrics, $\mathrm{pH}$ and $\Omega_{\mathrm{arag}}$, can vary quite differently in upwelling vs. non-upwelling-dominated systems and in warm southern vs. cold northern waters. As organisms respond to $\mathrm{pH}$ and $\Omega_{\text {arag }}$ differently (both during development and calcification $)^{14}$, our findings emphasize the importance of examining multiple aspects of organismal and ecosystem responses to ocean acidification with respect to $p \mathrm{CO}_{2}, \mathrm{pH}, \Omega_{\text {arag }}$, and DIC changes under warmer and higher $\mathrm{CO}_{2}$ future ocean conditions.

Recently, contrasting seasonal cycle responses of $\Omega_{\mathrm{arag}},\left[\mathrm{H}^{+}\right]$, $\mathrm{pH}$, and $p \mathrm{CO}_{2}$ to DIC increases throughout the global surface ocean have been shown with observations ${ }^{10}$ and models ${ }^{9,11,13,59}$. These findings, in addition to a more localized, estuarine study ${ }^{60}$, suggest that seasonal (and higher-frequency) variability may intensify more rapidly on upwelling-dominated and cold highlatitude margins due to their naturally lower buffering capacity and higher sensitivity to increasing $\mathrm{CO}_{2}$ content in the ocean. However, the absolute rates of $\Omega_{\text {arag }}$ decrease are faster in warm and high $\Omega_{\text {arag }}$ tropical and subtropical waters ${ }^{26}$. Our work further shows that there are substantial spatial differences in buffering capacities across the North American ocean margins and these differences imply a natural disparity in regional sensitivities 
a

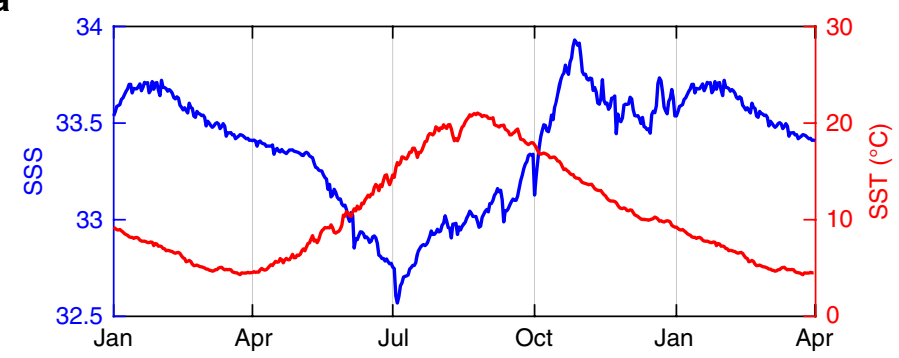

b

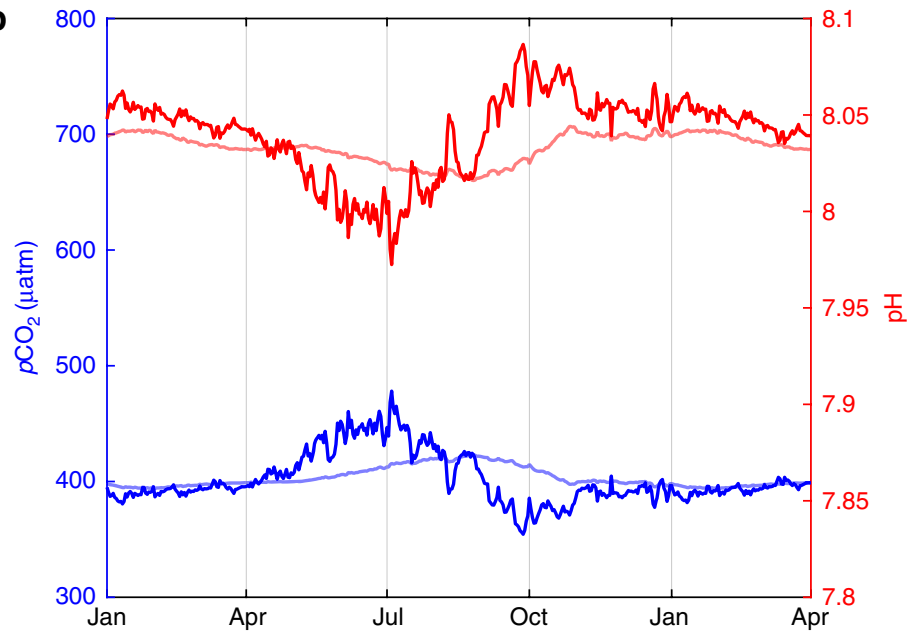

C

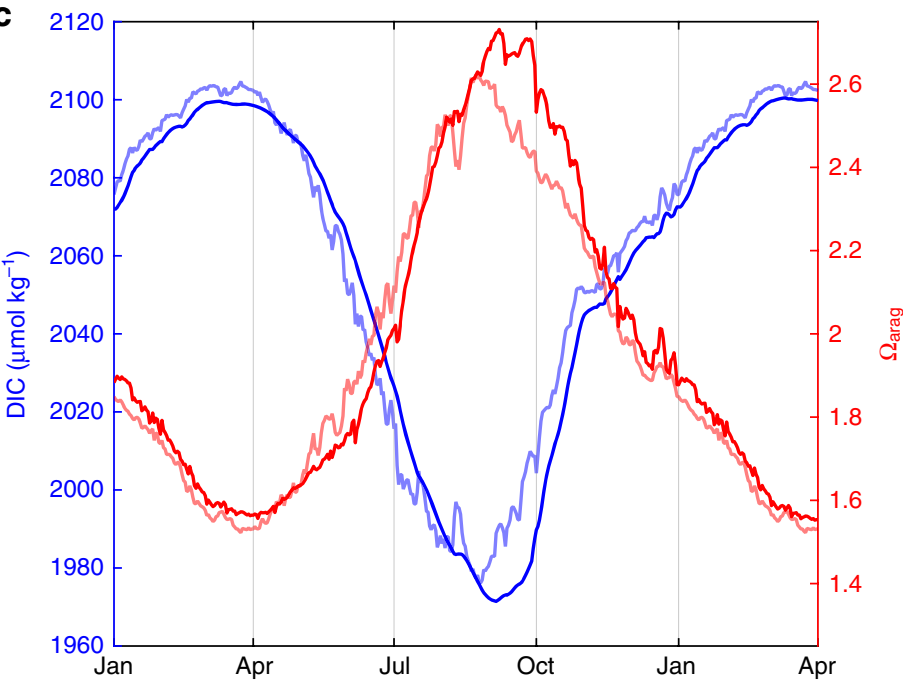

d

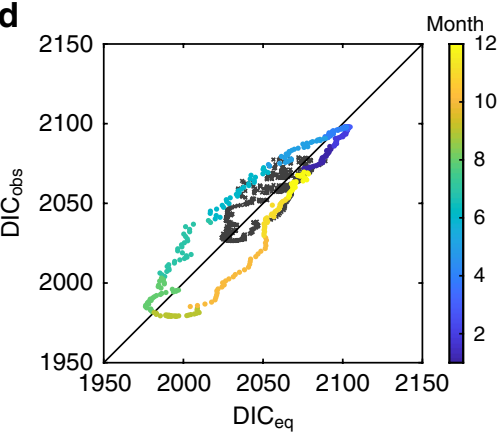

e

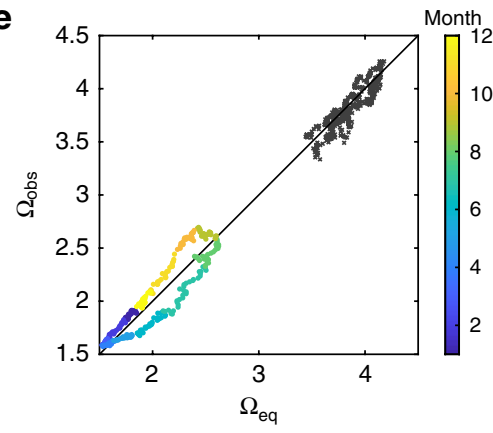

f

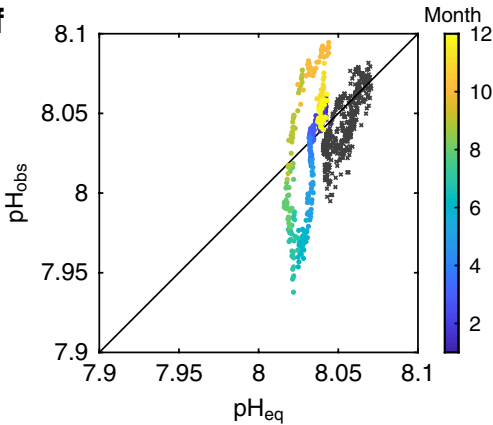

g

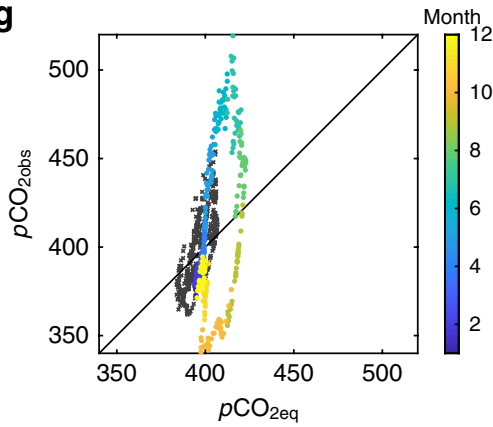

Fig. 6 Simulations of $\mathbf{p} \mathbf{C O}_{2}, \mathbf{p H}, \mathbf{D I C}$, and $\boldsymbol{\Omega}_{\text {arag. }}$. Simulations were run using a box model and values derived from the assumption of instantaneous $\mathrm{CO}_{2}$ equilibrium with the atmosphere. In the left column are a prescribed SST and SSS, $\mathbf{b}$ model-generated $p \mathrm{CO}_{2}$ and pH, and $\mathbf{c}$ model-generated DIC and $\Omega_{\mathrm{arag}}$ for Gulf of Maine waters. Heavy lines are box-model simulations and light lines are calculated values from instantaneous equilibrium with the atmosphere. For simplicity, we assume atmospheric $p \mathrm{CO}_{2}$ is seasonally invariant. In the right column, model observed $\mathbf{d} p \mathrm{CO}_{2}, \mathbf{e ~ p H ,} \mathbf{f} \mathrm{DIC}$, and $\mathbf{g} \Omega_{\text {arag }}$ are plotted against those predicted from equilibration with the atmosphere (eq), similar to those in Fig. 5. Symbols color coded by month represent the Gulf of Maine simulation (with colder temperature), and black symbols represent the South Atlantic Bight simulation (warmer temperature).

to ocean acidification. In particular, the RF distribution clearly draws our attention to ecosystems-including the CCS and northern-latitude coastal regions, such as the Gulf of Maine (Atlantic) and the Gulf of Alaska (Pacific) - as being particularly sensitive and vulnerable to anthropogenic $\mathrm{CO}_{2}$ forcing.

\section{Methods}

Description of the field program. Starting in 2007, under the auspices of National Oceanic and Atmospheric Administration (NOAA)'s Climate Program Office and, since its inception in 2010, Ocean Acidification Program, NOAA Pacific Marine
Environmental Laboratory and NOAA Atlantic Oceanographic and Meteorological Laboratory, in collaboration with academic partners and international collaborators, have conducted multiple surveys of the North American ocean margins. The most recent quality-controlled survey data are from the East Coast Ocean Acidification (ECOA) and Gulf of Alaska cruises in summer 2015, the West Coast Ocean Acidification (WCOA) cruise in late spring 2016, and the GOM Ecosystem and Carbon Cycle (GOMECC) cruise in summer 2017. Results from these cruises are presented in Fig. 2 and 3 along the coastlines of the North American continent and associated ocean margins, while previous cruises in the same regions (West Coast: late spring 2007 and late summer 2011, 2012, and 2013; GOM and Atlantic: summer 2007 and 2012). In addition, data from the Scotian Shelf and Labrador Sea as well as the Mexico Pacific coast, although limited, are included to extend the 
geographic coverage. Supplementary Table 2 summarizes the relevant cruise information.

In this work, all DIC samples were measured at sea by coulometric titration using a modified Single-Operator Multi-Metabolic Analyzer system, and TA was measured by acidimetric titration using the open cell method ${ }^{61,62}$. Both DIC and TA measurements were calibrated daily using Certified Reference Materials from Dr. Andrew Dickson's laboratory at Scripps Institution of Oceanography. The overall uncertainty of each of these two measurements is $\pm 2 \mu \mathrm{mol} \mathrm{kg}^{-1}$. DO was measured by a Winkler titration technique. Detailed descriptions are available at, for ECOA 2015, [https://www.nodc.noaa.gov/oads/data/0159428.xml] or [https:// doi.org/10.7289/v5vt1q40], for WCOA 2016, [https://www.nodc.noaa.gov/oads/ data/0169412.xml] or [https://doi.org/10.7289/v5v40shg], for GOMECC 2017, [https://www.nodc.noaa.gov/oads/data/0188978.xml] or [https://doi.org/10.25921/ yy5k-dw60], and for AZMP, [https://www.dfo-mpo.gc.ca/science/data-donnees/ biochem/index-eng.html].

For the purpose of examining spatial distributions, $\mathrm{pH}, \mathrm{pCO}$, and $\Omega_{\text {arag }}$ were calculated from DIC and TA together with nutrient concentrations using the CO2SYS program ${ }^{63}$ applying the carbonic acid dissociation constants of Mehrbach et al. ${ }^{64}$ as refitted by Dickson and Millero ${ }^{65}$. We use the DIC-TA pair because both parameters are available and were measured at high quality during all cruises. Good internal consistency among multiple parameters was observed and potential issues were identified in an earlier study ${ }^{66} . \mathrm{pH}$ is expressed on the total proton concentration scale ${ }^{67}$. $\Omega_{\text {arag }}$ is defined as the concentration product of dissolved calcium and carbonate ions divided by the aragonite mineral solubility product ${ }^{68}$.

DIC, $\Omega_{\text {arag, }} \mathbf{p H}$, and $p \mathrm{CO}_{2}$ at equilibrium with atmospheric $\mathbf{p C O}$. The values at equilibrium are calculated assuming that seawater $p \mathrm{CO}_{2}$ is in equilibrium with annual mean atmospheric $p \mathrm{CO}_{2}$. In this case, the input pair to CO2SYS is $p \mathrm{CO}_{2}$ and TA. The atmospheric $\mathrm{CO}_{2}$ data, as a dry air mole fraction, was obtained from the Mauna Loa Observatory, Hawaii.

Box-model simulation. To study the relationships that control surface-ocean carbonate parameters and air-sea $\mathrm{CO}_{2}$ fluxes, we use a box model to simulate an idealized mixed layer. The box model simulates the carbonate systems as a homogeneous surface-ocean water mass located either in the North-West Atlantic (NWA, $\left.40.1-42.5^{\circ} \mathrm{N}, 69.2-67.5^{\circ} \mathrm{W}\right)$ and South Atlantic Bight (SAB, $28.3^{\circ} \mathrm{N}-29.7^{\circ} \mathrm{N}$, $\left.77.6^{\circ} \mathrm{W}-79.2^{\circ} \mathrm{W}\right)$. The model is driven by realistic temperatures and salinities from the Mercator $1 / 12^{\circ}$ data-assimilated General Circulation Model with a daily resolution in time ${ }^{69}$

The carbonate system is defined from DIC and TA and re-adjusted to changes in temperature and salinity at each time step using the CO2SYS package 63 . Throughout the model simulation, TA is calculated from prescribed salinity ${ }^{61,69}$. The model is initiated with the carbonate system defined by $p \mathrm{CO}_{2}$ in equilibrium with atmospheric values and $\mathrm{TA}\left(\mathrm{TA}_{t 0}\right)$ defined by initial salinity ${ }^{70}$. DIC is calculated from $p \mathrm{CO}_{2(\mathrm{aq})}, \mathrm{TA}_{t 0}$, temperature, and salinity at $t=0$. The model is spun up for 180 days using prescribed physical and biological conditions as described above. $p \mathrm{CO}_{2} t(\mathrm{aq})$ is calculated using CO2SYS as well. $\Delta \mathrm{DIC}_{\mathrm{Bio}}$ and $\Delta \mathrm{DIC}_{\mathrm{Vertical}}$ are prescribed (see below), while $\Delta p \mathrm{CO}_{2}$ air-sea calculated at each time step using the relationship $\Delta p \mathrm{CO}_{2 \text { air-sea }}=0.24 \times k \times$ $K_{0} \times\left(p \mathrm{CO}_{2 \_t(\mathrm{aq})}-\left(p \mathrm{CO}_{2 \_(\mathrm{atm})}\right) . K_{0}\right.$ is the $\mathrm{CO}_{2}$ gas solubility ${ }^{71}$ and $k$ is defined as $k=0.251 \times W^{2} \times(S c / 660)^{-0.5}$, where $W$ is wind speed in $\mathrm{m} \mathrm{s}^{-1}$ and $S c$ is the Schmidt number 72,73

Biological production is assessed from weekly averages of daily changes in satellite-derived chlorophyll (Chl) for the year 2015 using the daily MODIS aqua 4$\mathrm{km}$ level 3 product $^{74}$. We extract daily time series for each grid cell that falls within the NWA and SAB model regions, identify all pairs of consecutive days with valid data, and convert changes in Chl to a carbon flux by using a fixed C:Chl ratio of 60 (ref. ${ }^{75}$ ). The resulting weekly averages are interpolated to daily time series. The resulting change in DIC due to biological production is significantly smaller than other sources and sinks in the current study. The highest net community production (NCP) values we get are on the order of $0.1 \mathrm{mmol} \mathrm{C} \mathrm{day}^{-1} \mathrm{~m}^{-3}$. This corresponds to $\sim 50 \mathrm{mg} \mathrm{C} \mathrm{m}^{-2} \mathrm{day}^{-1}$. Satellite-derived net primary production (NPP) is on the order of $400 \mathrm{mg} \mathrm{C} \mathrm{m}^{-2}$ day $^{-1}$ and with an expected NCP to NPP ratio of $\sim 10 \%$; thus, our biological production parameters are reasonable.

Winds are prescribed to $7 \mathrm{~m} \mathrm{~s}^{-1}$ in the summer and $10.5 \mathrm{~m} \mathrm{~s}^{-1}$ in the winter, to be consistent with representative wind data from the NOAA/Seawinds blended wind data set ${ }^{69}$. Winter mixing in NWA is simulated by adding $0.1 \mathrm{mmol} \mathrm{m}^{-3}$ DIC daily from October to February (over 155 days). The value is based on a scaling analysis of vertical DIC gradients and diffusivity estimates in the region based on observational in 2015 in the NWA region. Literature values of physical vertical diffusion combined with vertical profiles of DIC from the ECOA 2015 cruise suggests that diffusive transports of DIC is negligible during summer. We use constant winds to minimize noise and to isolate the effect by changes in solubility on the carbonate system. Atmospheric $p \mathrm{CO}_{2}$ is set to $395 \mu \mathrm{atm}$.

Specifically, the forward iteration from time $t \_n$ to $t \_n+1$ is performed by the following steps:

$\mathrm{DIC}_{t+1}=\mathrm{DIC}_{t}+\Delta p \mathrm{CO}_{2 \_ \text {air-sea }}+\Delta \mathrm{DIC}_{\mathrm{Bio}}+\Delta \mathrm{DIC}_{\text {Vertical }}$.

1. Calculate the carbonate system defined by temperature, salinity, DIC, and TA at $t_{-} n$.
2. Apply changes to the DIC concentration at $t \_n+1$ by biological processes, vertical mixing and air-sea exchange (based on $p \mathrm{CO}_{2}$ values at $t \_n$ ).

3. Recalculate the carbonate system using temperature, salinity, and TA at $t_{-} n$, and DIC at $t+n+1$.

4. Record $\mathrm{pH}, p \mathrm{CO}_{2}$, and $\Omega_{\mathrm{arag}}$ at $t+n+1$.

The reason to use temperature, salinity, and TA at $t \_n$ when performing step 3 is to make sure that all carbon parameters are calculated using the same physical conditions. All the details are given inside the coding: https://doi.org/10.5281/ zenodo. 3833678

We also calculate $\mathrm{DIC}_{\mathrm{eq}}$, a property that is based on the same TA, salinity, and temperature as the model but with $p \mathrm{CO}_{2(\mathrm{aq})}$ relaxed to $p \mathrm{CO}_{2(\mathrm{~atm})}$, which can be interpreted as the air-sea exchange being infinitely fast. Here for simplicity, we assume $p \mathrm{CO}_{2(\mathrm{~atm})}$ equals the dry $\mathrm{CO}_{2}$ mole fraction.

Statistical information. We used the built-in Matlab function (corrcoef) to compute the correlation coefficients (https://www.mathworks.com/help/matlab/ ref/corrcoef.htl).

\section{Data availability}

Discrete bottle data from all NOAA ocean acidification regional research cruises are available at NOAA's National Centers for Environmental Information. For ECOA 2015 [https://www.nodc.noaa.gov/oads/data/0159428.xml] or [https://doi.org/10.7289/ v5vt1q40]; for WCOA 2016, [https://www.nodc.noaa.gov/oads/data/0169412.xml] or [https://doi.org/10.7289/v5v40shg]; for GOMECC 2017, [https://www.nodc.noaa.gov/ oads/data/0188978.xml] or [https://doi.org/10.25921/yy5k-dw60], and for AZMP, [https://www.dfo-mpo.gc.ca/science/data-donnees/biochem/index-eng.html]. Atmospheric $\mathrm{CO}_{2}$ data are available at https://www.esrl.noaa.gov/gmd/ccgg/trends/data. html.

\section{Code availability}

The box model was written in python and the code can be found at https://doi.org/ 10.5281/zenodo.3833678

Received: 20 July 2019; Accepted: 23 March 2020;

Published online: 01 June 2020

\section{References}

1. Bates, N. R. et al. Detecting anthropogenic carbon dioxide uptake and ocean acidification in the North Atlantic Ocean. Biogeosciences 9, 2509-2522 (2012).

2. Orr, J. C. et al. Anthropogenic ocean acidification over the twenty-first century and its impact on calcifying organisms. Nature 437, 681-686 (2005)

3. Caldeira, K. \& Wickett, M. E. Anthropogenic carbon and ocean pH. Nature 425, 365 (2003).

4. Brewer, P. G. A changing ocean seen with clarity. Proc. Natl Acad. Sci. USA 106, 12213-12214 (2009).

5. Takahashi, T. et al. Climatological distributions of $\mathrm{pH}, \mathrm{pCO}$, total $\mathrm{CO}_{2}$, alkalinity, and $\mathrm{CaCO}_{3}$ saturation in the global surface ocean, and temporal changes at selected locations. Mar. Chem. 164, 95-125 (2014).

6. Jiang, L.-Q. et al. Climatological distribution of aragonite saturation state in the global oceans. Glob. Biogeochem. Cycles 29, 2015GB005198 (2015).

7. Völker, C., Wallace, D. W. R. \& Wolf-Gladrow, D. A. On the role of heat fluxes in the uptake of anthropogenic carbon in the North Atlantic. Glob. Biogeochem. Cycles 16, 85-89 (2002).

8. Jiang, L.-Q., Carter, B. R., Feely, R. A., Lauvset, S. K. \& Olsen, A. Surface ocean pH and buffer capacity: past, present and future. Sci. Rep. 9, 18624 (2019).

9. McNeil, B. I. \& Sasse, T. P. Future ocean hypercapnia driven by anthropogenic amplification of the natural $\mathrm{CO}_{2}$ cycle. Nature 529, 383-386 (2016).

10. Landschützer, P., Gruber, N., Bakker, D. C. E., Stemmler, I. \& Six, K. D. Strengthening seasonal marine $\mathrm{CO}_{2}$ variations due to increasing atmospheric $\mathrm{CO}_{2}$. Nat. Clim. Chang. 8, 146-150 (2018).

11. Kwiatkowski, L. \& Orr, J. C. Diverging seasonal extremes for ocean acidification during the twenty-first century. Nat. Clim. Chang. 8, 141-145 (2018).

12. Perez, F. F. et al. Meridional overturning circulation conveys fast acidification to the deep Atlantic Ocean. Nature 554, 515 (2018).

13. Fassbender, A. J., Rodgers, K. B., Palevsky, H. I. \& Sabine, C. L. Seasonal asymmetry in the evolution of surface ocean $p \mathrm{CO}_{2}$ and $\mathrm{pH}$ thermodynamic drivers and the influence on sea-air $\mathrm{CO}_{2}$ flux. Glob. Biogeochem. Cycles 32, 1476-1497 (2018)

14. Waldbusser, G. G. et al. Ocean acidification has multiple modes of action on bivalve larvae. PLOS ONE 10, e0128376 (2015).

15. Albright, R. et al. Carbon dioxide addition to coral reef waters suppresses net community calcification. Nature 555, 516 (2018). 
16. Riebesell, U. \& Gattuso, J.-P. Lessons learned from ocean acidification research. Nat. Clim. Chang. 5, 12 (2014).

17. Cai, W.-J. et al. Acidification of subsurface coastal waters enhanced by eutrophication. Nat. Geosci. 4, 766-770 (2011).

18. Feely, R. A. et al. The combined effects of ocean acidification, mixing, and respiration on $\mathrm{pH}$ and carbonate saturation in an urbanized estuary. Estuar. Coast. Shelf Sci. 88, 442-449 (2010).

19. Hagens, M. et al. Biogeochemical processes and buffering capacity concurrently affect acidification in a seasonally hypoxic coastal marine basin. Biogeosciences 12, 1561-1583 (2015).

20. Sunda, W. G. \& Cai, W.-J. Eutrophication induced $\mathrm{CO}_{2}$-acidification of subsurface coastal waters: Interactive effects of temperature, salinity, and atmospheric $P_{\mathrm{CO} 2}$. Environ. Sci. Technol. 46, 10651-10659 (2012).

21. Silbiger, N. J. \& Sorte, C. J. B. Biophysical feedbacks mediate carbonate chemistry in coastal ecosystems across spatiotemporal gradients. Sci. Rep. 8, 796 (2018)

22. Kleypas, J. A., Anthony, K. R. N. \& Gattuso, J.-P. Coral reefs modify their seawater carbon chemistry - case study from a barrier reef (Moorea, French Polynesia). Glob. Chang. Biol. 17, 3667-3678 (2011).

23. Signorini, S. R. et al. Surface ocean $p \mathrm{CO}_{2}$ seasonality and sea-air $\mathrm{CO}_{2}$ flux estimates for the North American east coast. J. Geophys. Res. Ocean 118, 1-22 (2013).

24. Wang, Z. A. et al. The marine inorganic carbon system along the Gulf of Mexico and Atlantic coasts of the United States: insights from a transregional coastal carbon study. Limnol. Oceanogr. 58, 325-342 (2013).

25. Wanninkhof, R. et al. Ocean acidification along the Gulf Coast and East Coast of the USA. Cont. Shelf Res. 98, 54-71 (2015).

26. Feely, R. A. et al. The combined effects of acidification and hypoxia on $\mathrm{pH}$ and aragonite saturation in the coastal waters of the California current ecosystem and the northern Gulf of Mexico. Cont. Shelf Res. 152, 50-60 (2018).

27. Feely, R. A., Sabine, C. L., Hernandez-Ayon, J. M., Ianson, D. \& Hales, B. Evidence for upwelling of corrosive 'acidified' water onto the continental shelf. Science (80) 320, 1490-1492 (2008).

28. DeGrandpre, M. D., Olbu, G. J., Beatty, C. M. \& Hammar, T. R. Air-sea $\mathrm{CO}_{2}$ fluxes on the US Middle Atlantic Bight. Deep. Res. Part II 49, 4355-4367 (2002).

29. Huang, W.-J., Cai, W.-J., Wang, Y., Lohrenz, S. E. \& Murrell, M. C. The carbon dioxide system on the Mississippi River-dominated continental shelf in the northern Gulf of Mexico: 1. Distribution and air-sea $\mathrm{CO}_{2}$ flux. J. Geophys. Res. Ocean 120, 1429-1445 (2015).

30. Jiang, L.-Q., Cai, W.-J. \& Wang, Y. A comparative study of carbon dioxide degassing in river- and marine-dominated estuaries. Limnol. Oceanogr. 53, 2603-2615 (2008).

31. Salisbury, J., Green, M., Hunt, C. \& Campbell, J. Coastal acidification by rivers: a threat to shellfish? Eos Trans. AGU 89, 513-514 (2008).

32. Borges, A. V. \& Gypens, N. Carbonate chemistry in the coastal zone responds more strongly to eutrophication than ocean acidification. Limnol. Oceanogr. 55, 346-353 (2010).

33. Fassbender, A. J., Sabine, C. L., Feely, R. A., Langdon, C. \& Mordy, C. W. Inorganic carbon dynamics during northern California coastal upwelling. Cont. Shelf Res. 31, 1180-1192 (2011).

34. Fassbender, A. J., Sabine, C. L. \& Feifel, K. M. Consideration of coastal carbonate chemistry in understanding biological calcification. Geophys. Res. Lett. 43, 4467-4476 (2016).

35. Salisbury, J. E. \& Jönsson, B. F. Rapid warming and salinity changes in the Gulf of Maine alter surface ocean carbonate parameters and hide ocean acidification. Biogeochemistry 141, 401-418 (2018).

36. Carter, B. R., Toggweiler, J. R., Key, R. M. \& Sarmiento, J. L. Processes determining the marine alkalinity and calcium carbonate saturation state distributions. Biogeosciences 11, 7349-7362 (2014).

37. Richaud, B., Kwon, Y.-O., Joyce, T. M., Fratantoni, P. S. \& Lentz, S. J. Surface and bottom temperature and salinity climatology along the continental shelf off the Canadian and U.S. East Coasts. Cont. Shelf Res. 124, 165-181 (2016).

38. Atkinson, L. P., Lee, T. N., Blanton, J. O. \& Chandler, W. S. Climatology of the southeastern United States continental shelf waters. J. Geophys. Res. Ocean 88, $4705-4718$ (1983).

39. Wiseman, W. J., Rabalais, N. N., Turner, R. E., Dinnel, S. P. \& MacNaughton, A. Seasonal and interannual variability within the Louisiana coastal current: stratification and hypoxia. J. Mar. Syst. 12, 237-248 (1997).

40. Cai, W.-J. et al. Alkalinity distribution in the western North Atlantic Ocean margins. J. Geophys. Res. 115, C08014 (2010).

41. Egleston, E. S., Sabine, C. L. \& Morel, F. M. M. Revelle revisited: buffer factors that quantify the response of ocean chemistry to changes in DIC and alkalinity. Glob. Biogeochem. Cycles 24, GB1002 (2010).

42. Guo, X. et al. Carbon dynamics and community production in the Mississippi river plume. Limnol. Oceanogr. 57, 1-17 (2012).
43. Jiang, Z.-P., Tyrrell, T., Hydes, D. J., Dai, M. \& Hartman, S. E. Variability of alkalinity and the alkalinity-salinity relationship in the tropical and subtropical surface ocean. Glob. Biogeochem. Cycles 28, 729-742 (2014).

44. Townsend, D. W. et al. Water masses and nutrient sources to the Gulf of Maine. J. Mar. Res. 73, 93-122 (2015).

45. Davis, R. A. in Habitats and Biota of the Gulf of Mexico: Before the Deepwater Horizon Oil Spill (ed. Ward, C.) https://doi.org/10.1007/978-1-4939-3447-8_3 (2017).

46. Jacox, G., Moore, M., Edwards, A. \& Fiechter, J. Spatially resolved upwelling in the California Current System and its connections to climate variability. Geophys. Res. Lett. 41, 3189-3196 (2014).

47. Turi, G., Lachkar, Z. \& Gruber, N. Spatiotemporal variability and drivers of $p \mathrm{CO}_{2}$ and air-sea $\mathrm{CO}_{2}$ fluxes in the California Current System: an eddyresolving modeling study. Biogeosciences 11, 671-690 (2014).

48. Hickey, B. M. The California current system-hypotheses and facts. Prog. Oceanogr. 8, 191-279 (1979).

49. Hales, B., Takahashi, T. \& Bandstra, L. Atmospheric $\mathrm{CO}_{2}$ uptake by a coastal upwelling system. Glob. Biogeochem. Cycles 19, GB1009 (2005).

50. Evans, W., Mathis, J. T., Winsor, P., Statscewich, H. \& Whitledge, T. E. A regression modeling approach for studying carbonate system variability in the northern Gulf of Alaska. J. Geophys. Res. Ocean 118, 476-489 (2013).

51. Franco, A. C. et al. Air-sea $\mathrm{CO}_{2}$ fluxes above the stratified oxygen minimum zone in the coastal region off Mexico. J. Geophys. Res. Ocean 119, 2923-2937 (2014).

52. Broecker, W. S., Takahashi, T., Simpson, H. J. \& Peng, T.-H. Fate of fossil fuel carbon dioxide and the global carbon budget. Science (80) 206, 409 LP-409418 (1979).

53. Sundquist, E. T., Plummer, L. N. \& Wigley, T. M. L. Carbon-dioxide in the ocean surface-homogeneous buffer factor. Science (80) 204, 1203-1205 (1979).

54. Frankignoulle, $\mathrm{M}$. A complete set of buffer factors for acid-base $\mathrm{CO}_{2}$ system in seawater. J. Mar. Syst. 5, 111-118 (1994).

55. Álvarez, M. et al. The $\mathrm{CO}_{2}$ system in the Mediterranean Sea: a basin wide perspective. Ocean Sci. 10, 69-92 (2014).

56. Fassbender, A. J., Sabine, C. L. \& Palevsky, H. I. Nonuniform ocean acidification and attenuation of the ocean carbon sink. Geophys. Res. Lett. 44, 8404-8413 (2017)

57. Broecker, W. S. \& Peng, T. H. Tracers in the Sea, 690pp (Eldigio, Palisades, New York, 1982).

58. Jiang, L., Carter, B. R., Feely, R. A., Lauvset, S. K. \& Olsen, A. Surface ocean $\mathrm{pH}$ and buffer capacity: past, present, and future. Sci. Rep. 9, 18624 (2020).

59. Hauck, J. \& Völker, C. Rising atmospheric $\mathrm{CO}_{2}$ leads to large impact of biology on Southern Ocean $\mathrm{CO}_{2}$ uptake via changes of the Revelle factor. Geophys. Res. Lett. 42, 1459-1464 (2015).

60. Pacella, S. R., Brown, C. A., Waldbusser, G. G., Labiosa, R. G. \& Hales, B. Seagrass habitat metabolism increases short-term extremes and long-term offset of $\mathrm{CO}_{2}$ under future ocean acidification. Proc. Natl Acad. Sci. USA 115, 3870 LP-3873875 (2018).

61. Dickson, A. G., Sabine, C. L. \& Christian, J. R. Guide to best practices for ocean $\mathrm{CO}_{2}$ measurements. PICES Spec. Publ. 3, https://doi.org/10.1159/ 000331784 (2007).

62. Johnson, K. M., Kortzinger, A., Mintrop, L., Duinker, J. C. \& Wallace, D. W. R. Coulometric total carbon dioxide analysis for marine studies: measurement and internal consistency of underway $\mathrm{TCO}_{2}$ concentrations. Mar. Chem. 67, 123-144 (1999).

63. Van Heuven, S., Pierrot, D., Rae, J. W. B. \& Wallace, D. W. R. MATLAB Program Developed for $\mathrm{CO}_{2}$ System Calculations. ORNL/CDIAC-105b, 530 (Carbon Dioxide Information Analysis Center, Oak Ridge National Laboratory, US Department of Energy, Oak Ridge, 2009).

64. Mehrbach, C., Culberson, C. H., Hawley, J. E. \& Pytkowicz, R. M. Measurement of the apparent dissociation constants of carbonic acid in seawater at atmospheric pressure. Limnol. Oceanogr. 18, 897-907 (1973).

65. Dickson, A. G. \& Millero, F. J. A comparison of the equilibrium constants for the dissociation of carbonic acid in seawater media. Deep Sea Res. 34, 1733-1743 (1987)

66. Patsavas, M. C., Byrne, R. H., Wanninkhof, R., Feely, R. A. \& Cai, W.-J. Internal consistency of marine carbonate system measurements and assessments of aragonite saturation state: Insights from two U.S. coastal cruises. Mar. Chem. 176, 9-20 (2015).

67. Dickson, A. G. pH buffers for sea water media based on the total hydrogen ion concentration scale. Deep Sea Res. 40, 107-118 (1993).

68. Mucci, A. The solubility of calcite and aragonite in seawater at various salinity, temperatures, and one atmosphere total pressure. Am. J. Sci. 283, 789-799 (1983).

69. Lellouche, J.-M. et al. Evaluation of global monitoring and forecasting systems at Mercator Océan. Ocean Sci. Discuss. 9, 1123-1185 (2012).

70. Cai, W.-J. et al. Alkalinity distribution in the western North Atlantic Ocean margins. J. Geophys. Res. Ocean. 115, C08014 (2010). 
71. Weiss, R. F. Carbon dioxide in water and seawater: the solution of a non-ideal gas. Mar. Chem. 2, 203-215 (1974).

72. Wanninkhof, R. Relationship between wind speed and gas exchange over the ocean. J. Geophys. Res. 97, 7373-7382 (1992).

73. Wanninkhof, R. Relationship between wind speed and gas exchange over the ocean revisited. Limnol. Ocean. Methods 12, 351-362 (2014).

74. NASA Goddard Space Flight Center, Ocean Ecology Laboratory, Ocean Biology Processing Group. Moderate-Resolution Imaging Spectroradiometer (MODIS) Aqua Chlorophyll Data; 2018 Reprocessing. NASA OB.DAAC, Greenbelt, MD, USA https://doi.org/10.5067/AQUA/MODIS/L3M/CHL/2018 (2018).

75. Jackson, T., Sathyendranath, S. \& Platt, T. An exact solution for modeling photoacclimation of the carbon-to-chlorophyll ratio in phytoplankton. Front. Mar. Sci. 4, 283 (2017).

\section{Acknowledgements}

Data reported in this work were collected under the auspices of the National Oceanic and Atmospheric Administration (NOAA)'s Global Carbon Cycle (GCC) and Ocean Acidification Programs (OAP). We thank captains and crew of all vessels involved in collecting the data at sea and the outstanding technical staff, students, postdocs, and PIs at NOAA and partner labs for their collaboration on the first decade of NOAA ocean acidification cruises. The Canadian data were collected with support from NSF and Department of Fisheries and Oceans (DFO) Aquatic Climate Change Adaptation Services Program (ACCASP). We are grateful to the governments of Canada and the United Mexican States for fishing licenses and research permission allowing us to conduct our research within their Exclusive Economic Zones during all cruises (PPFE/DGOPA-072/ 16, PPFE/DGOPA-137/17, EG0082017, EG00032016, No. 343609, and IDR-1279). W.-J. C was also supported by NSF (grant no OCE-1559279). B.J. was supported by Simons Foundation via grant no 549947 (SS). This is contribution number 4853 from the NOAA Pacific Marine Environmental Laboratory.

\section{Author contributions}

R.A.F. and S.R.A. are responsible for the design of the West Coast Ocean Acidification (WCOA) cruises. J.C. is responsible for the design of the Gulf of Alaska Coast Ocean Acidification cruises. J.E.S., W.-J.C., and R.W. are responsible for the design of the East Coast Ocean Acidification (ECOA) cruises. R.W. and L.B. are responsible for the design of the Gulf of Mexico Ecosystem and Carbon Cycle (GOMECC) cruises. K.A.-S. and P.P. are responsible for the Davis Strait work. J.M.H.-A. is response for the Mexican Pacific coastal data. L.-Q.J. compiled the initial list of cruise data. J.J.R., B.C., N.H., Q.L. and C.L. contributed to data collection efforts. Y.-Y.X. and W.-J.C. analyzed data. W.-J.C. prepared the paper. B.J. did the box-model simulation. L.X. and W.-J.C. did the temperature effect model. A.J.F., S.R.A., B.R.C., R.W., R.A.F., B.J., A.J.S., C.-T.A.C., and D.K.G. edited the paper. All authors contributed to the discussion and writing.

\section{Competing interests}

The authors declare no competing interests.

\section{Additional information}

Supplementary information is available for this paper at https://doi.org/10.1038/s41467020-16530-z.

Correspondence and requests for materials should be addressed to W.-J.C.

Peer review information Nature Communication thanks Marta Álvarez, Adam Subhas, and other, anonymous, reviewers for their contributions to the peer review of this work. Peer review reports are available.

Reprints and permission information is available at http://www.nature.com/reprints

Publisher's note Springer Nature remains neutral with regard to jurisdictional claims in published maps and institutional affiliations.

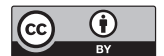

Open Access This article is licensed under a Creative Commons Attribution 4.0 International License, which permits use, sharing, adaptation, distribution and reproduction in any medium or format, as long as you give appropriate credit to the original author(s) and the source, provide a link to the Creative Commons license, and indicate if changes were made. The images or other third party material in this article are included in the article's Creative Commons license, unless indicated otherwise in a credit line to the material. If material is not included in the article's Creative Commons license and your intended use is not permitted by statutory regulation or exceeds the permitted use, you will need to obtain permission directly from the copyright holder. To view a copy of this license, visit http://creativecommons.org/ licenses/by/4.0/

(C) The Author(s) 2020 